\title{
Rippl-Rónai múzsái, híres kertjei, elveszett festményei és egy rejtélyes hamisítási ügy
}

\author{
HORVÁTH JÁNOS \\ Rippl-Rónai Megyei Hatókörű Városi Múzeum, H-7400 Kaposvár, Fő u. 10., \\ e-mail: horvanos@gmail.com
}

\begin{abstract}
HoRvátH, J.: Rippl-Rónai muses, famous gardens, lost paintings and a mysterious forgery case.

Abstract: The author published different short studies and stories about József Rippl-Rónai's biography and his works. An obscure document was also published about the origin of his house which known in Kaposvár as Róma villa. It is the first time to compile Lazarine's biography, French-born wife of the painter in which her tapestry of artistic activities was reviewed. Due to the modern style innovations, „Fifty drawings" titled and published by Rippl-Rónai in 1913 was also reported. In these studies, the English Fenella Lowell appeared as a model, who inspired nude women oil-paintings of Rippl-Rónai. An unknown letter from Rippl-Rónai's daughter, the German-born Amélie Feigl was documented. An RipplRónai's counterfeiting pastel was storied which was happened at the end of the artist's life (1927) during his illness.
\end{abstract}

Keywords: József Rippl-Rónai; Olga Máté, Lazarine, Fenella, pastel portrait, gobelin, fauve wash-drawing nudes.

\section{Bevezető}

Rippl-Rónai József életrajzával és művészetével kapcsolatos új kutatási eredményekről számol be az alábbi, hat eltérő témájú tanulmány. Az eltérések ellenére az a közös bennük, hogy kiindulásként egy közös forrás szolgált. Az itt felhasznált szakirodalomból kiemeljük a művész francia nevelt leányának, Paris Anellának az emlékiratát. Abban esik szó arról, hogy Rippl-Rónai francia felesége mely vidékről származik, abból tudtuk meg, hogy a művésznek született egy vér szerinti gyermeke, Anella adott információt a Fenella nevü modellről.

A témában ismertetünk egy kézzel írt dokumentumot, amelyben Rippl-Rónai József összefoglalta történeti ismereteit kaposvári birtokáról, a Róma-villa eredetéről. A művész által leírtak nyomán haladva értelmezzük, kibővítjük, kerekké tesszük a Rippl-Rónai által nevezetessé vált kaposvári birtok történetét. $A$ müvész életének párjáról, a francia feleségről, Lazarine-ról itt nyújtunk először életrajzi leírást. Kiemeljük iparművészi tehetségét, amely méltóvá tette őt, hogy Rippl-Rónai alkotótársa lehessen. Beszámolunk özvegyi életének bonyodalmairól, kiszolgáltatottságáról. Külön témaként foglalkozunk Rippl-Rónai József rajzaival. E helyen azokkal, amelyeket „Rippl-Rónai J. ötven rajza” címmel 1913-ban mappában jelentetett meg a Könyves Kálmán Mükiadó. A sajátos technikájú rajzok modelljeként tünt fel Fenella Lowell, aki érdekes személyiségével inspirálta Rippl-Rónai női aktos témájú olajképeit. Szólunk arról, hogy az aktos kompozíciók java része lappang és felkutatásuk jelentős eredménnyel szolgálhatna. Közreadunk egy Paris Anella által megőrzött levelet Rippl-Rónai ismeretlen leányától, a német születésű Feigl Amélietől, akinek homályos születési körülménye visszanyúlik 1887-re, a müncheni tanulóévekre. Végül foglalkozunk a hamisítások témájával. A Rippl-Rónai hamisítványok nagy száma súlyosan terheli az életmü kutathatóságát. Most az egyik legkorábbi hamisítási eset után nyomozunk, amely 1926-27 körül, tehát még a művész életében történt. Paris Anella megemlíti, hogy az idős Mester egy furcsa adósságot vállalt a Fränkel képkereskedővel történt megegyezéssel. Ennek nyomán foglalkozunk azzal a helyzettel, amikor Rippl-Rónai súlyos betegsége miatt már nem tudott rendesen dolgozni. Bekövetkezett az, amikor a festő keze nem engedelmeskedik az alkotói szellem utasításainak, s már nem születhetik teljes értékủ alkotás. A müvész emiatti kiszolgáltatottságában visszaélésekre adódott lehetőség.

\section{A Róma-villa eredete}

Rippl-Rónai József 1912-ben feljegyezte történeti ismereteit a Róma-villa eredetéről. A Magyar Nemzeti Galéria adattára őrzi azt a füzetet, amely egyéb bejegyzések mellett az alább idézett írást tartalmazza.

„Róma villa eredete

Eszterházy hercegtől cserélte be Skossa főbiró - füredi birtokáért. 72 hold volt az Eszterházy birtok. Később, mikor Skossa árverésre jutott, a sógora Würth Adolf vette meg potom 4005 forintokért - 6 éves birtoklás után a Németh Náci rábeszélésére eladta 10.000 forintokért Gundy György színésznekGundy János szőllője mellett, a mi még ma is Gundy birtok: Laczié. Gundy halála után - a vejéjé lett Breier színészé. Ez a Villát kiadta a föispánnak (a későbbi kereskedelmi miniszternek: Tallián Bélának.) Breier később Tallián 7 évi bérlése után - kiadta Brandt alezredesnek, aki később megvette. Ennek tönkremenetele után a még birtokában maradt park és három épület árverés útján Dobossyé lett, de még birtoklása előtt 800 korona ráfizetéssel én vettem meg 15.000 koronáért. Két év után a mellettünk levő 5 és $1 / 2$ katasztrális hold földet (régi Gundy részt) Peterkától 10.000 koronáért szintén megvettem. 1912. aug 22. Rippl-Rónai József. Szomszédjaim most Lerner Sándor építőmester - alulról Felül pedig Szabady János volt számvevő és Sipos vasúti ember. (Régi Gundy birtok) A villát villává Gundy csinálta illetőleg emeletre vette abból az egyszerü kis házikóból - amit még Skossa épittetett." (1-3. ábra) 
388

HORVÁTH JÁNOS

M. Shumisis forrunth

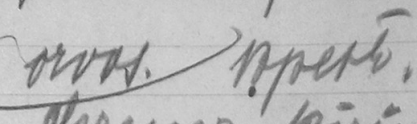

forunn-minite I. I.

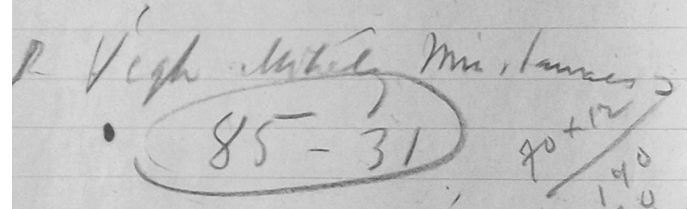

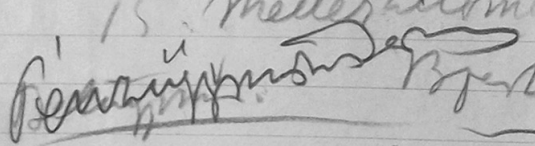

Reik Jlk inge

Vas atee 3. IV can

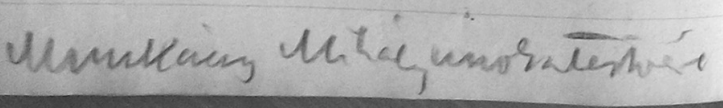

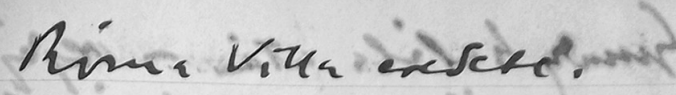

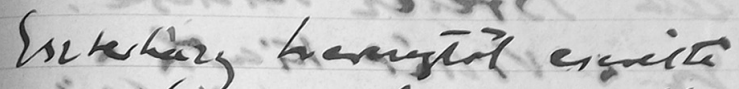

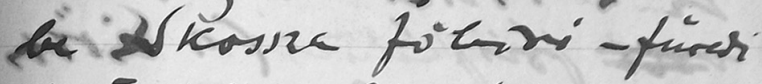

consicier. 72 hol mes a Intestiz. Gortosithon.

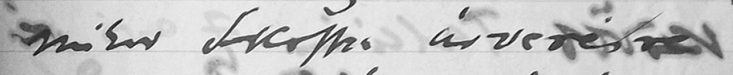

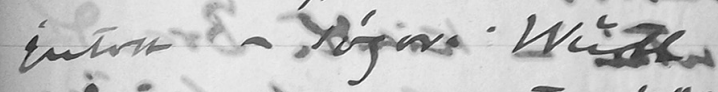

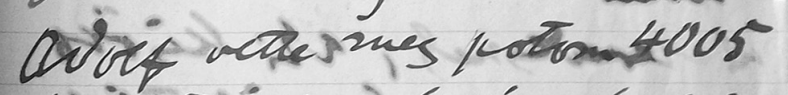
finim2orert 36 in Gros:

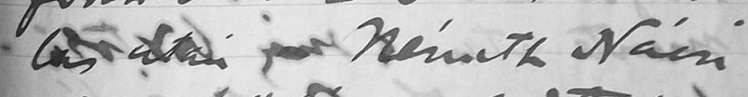

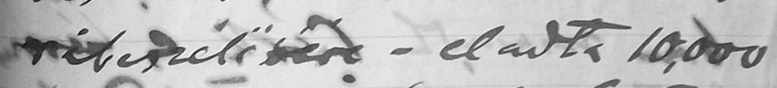

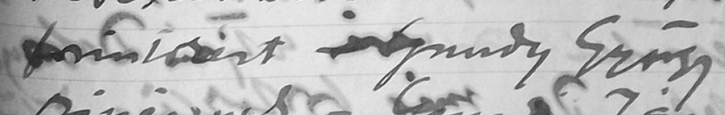

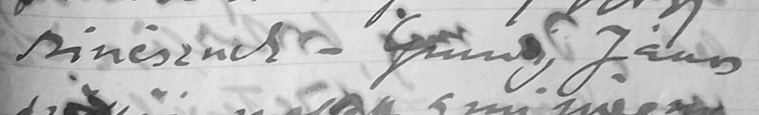

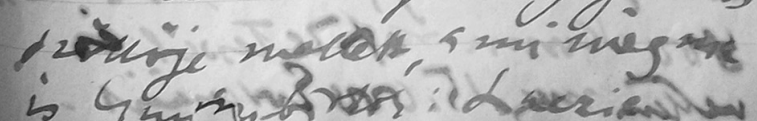

1. ábra. Ripp-Rónai jegyzetfüzete a Róma-villa eredetéről szóló írásával

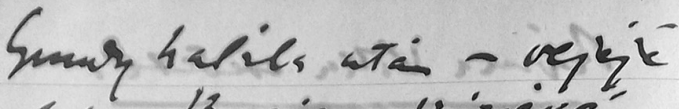

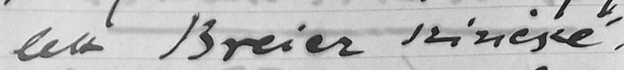
L 6 Vilvér taichts

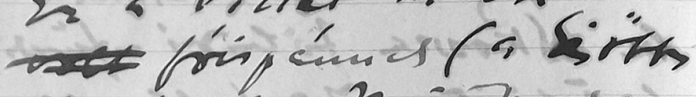
Mareikedelas Misonkand:

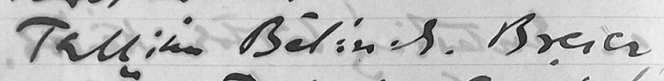

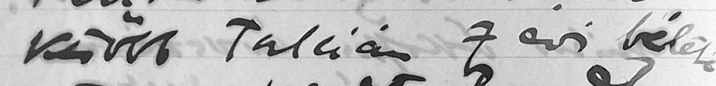
wTin - kinito brangl aleveratens, ir kistho mejoete. Enues tinime-

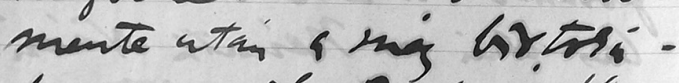
6 monit rork s kims

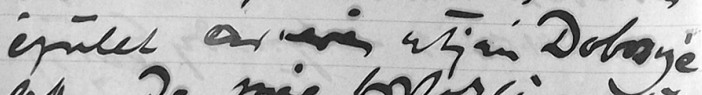

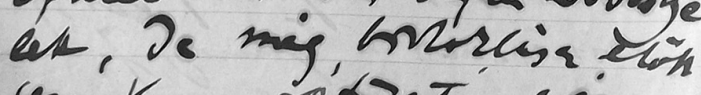
fors koms vakretesce a

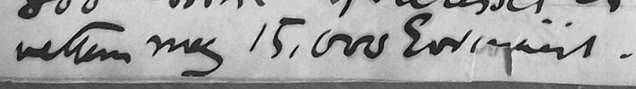

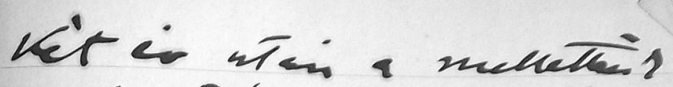
eno" is $1 / 2$ Ker nifis

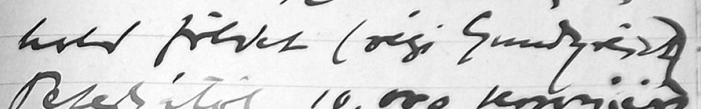
Belestítiot lo cono vemicios oxistes noquetems.

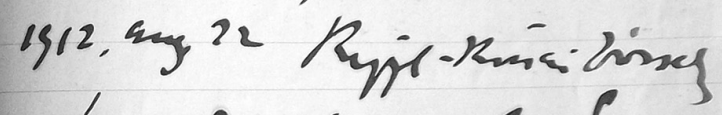

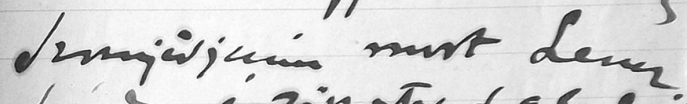

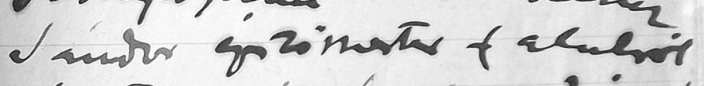

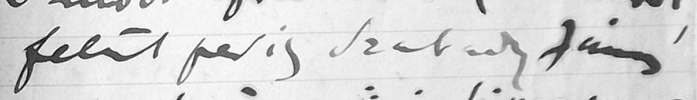

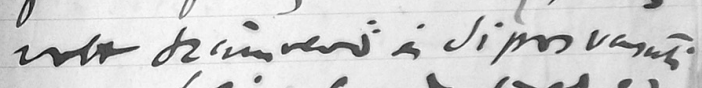
unber. (Rigi Snat 2 hrotos)

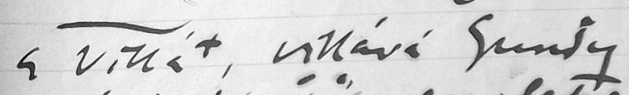
aimilis indiric molets. Wete abtit a e promis las hoirlo

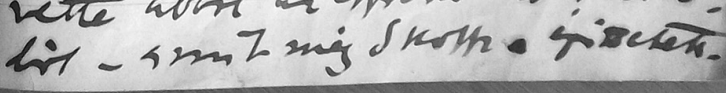

2. ábra. Rippl-Rónai írása a Róma-villáról 


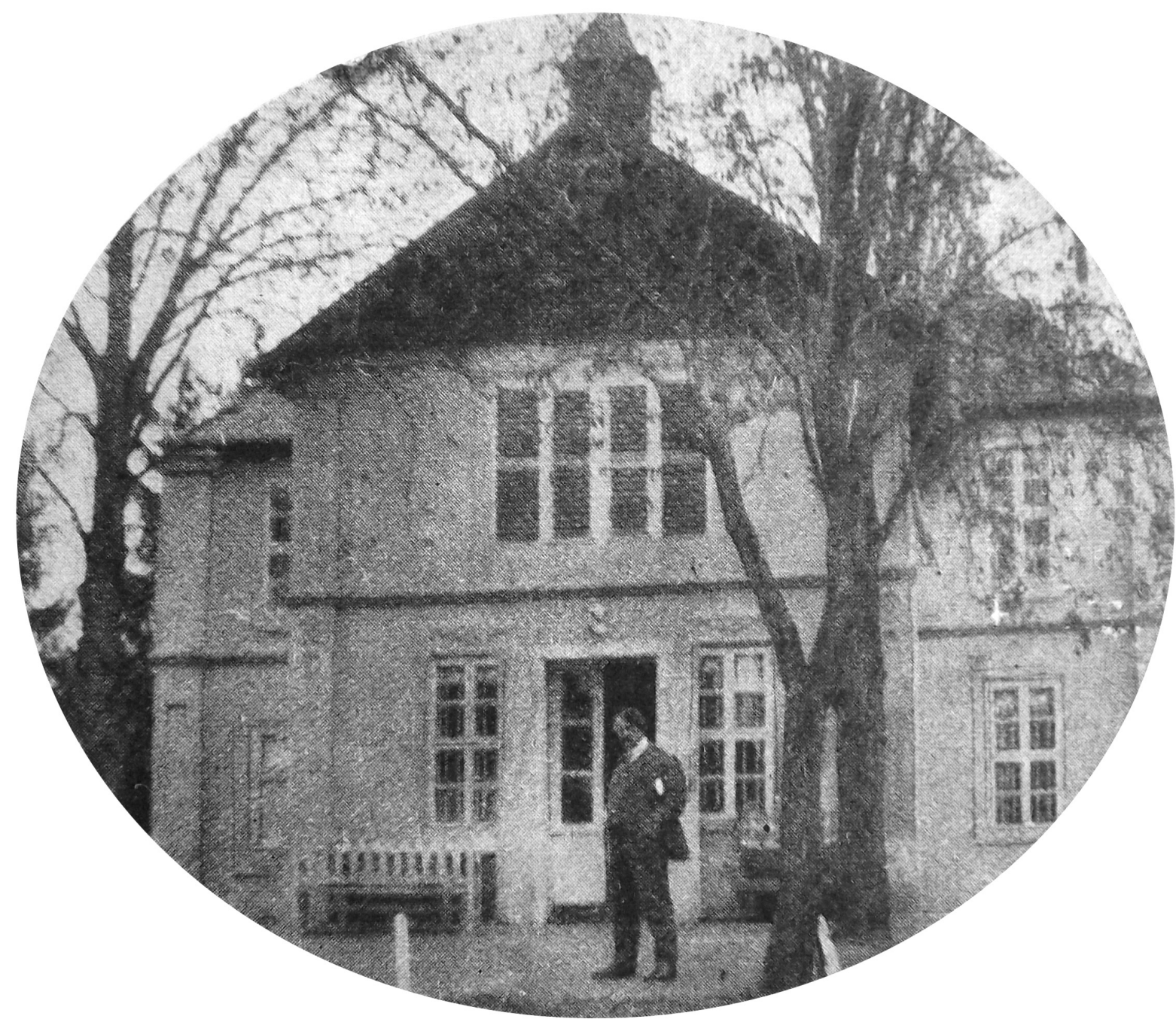

3. ábra. Rippl-Rónai József a Róma-villa előtt

Rippl-Rónai jegyzetének elolvasásával kérdések merülnek fel a hiányzó évszámok és az ismeretlen személynevek miatt. Biztosra vehető, hogy a művész áttekintéséhez nem állt rendelkezésre írásos dokumentum, csak a szóbeliség utáni emlékezet. RipplRónai krónikási tettét áthatotta a virágzó úri birtok gazdáját megillető büszkeség, és jó szokás szerint összesíteni akarta a Róma-villa korábbi tulajdonosait. A hiányosságok ellenére, ez az első és egyetlen olyan dokumentum, amely a ház tulajdonosától származik. Emiatt fontos közlemény az utókor számára.

Sorra vesszük a tulajdonosokat és levéltári kutatások alapján értelmezzük az írásban megnevezett személyeket. Mindezt megelőzően a Róma-hegy földrajzi elnevezésének kutatásáról is beszámolunk. Az 1732ben készült hercegi uradalmi összeírásban a Rómahegy, mint földrajzi név nem szerepel. Az 1784-ben készült II. József-féle katonai térkép szőlőnek tünteti fel. A Róma-hegy elnevezése csak száz évvel később bukkan elö, Pesty Frigyes történeti földrajzkutató említi: „Kiss és Nagyroma neveinek eredete bizonytalan, jó bor terem, a' hegy lántzolat rengeteg erdő volt, mely a tagositás alkalmával földbirtokká vált, - honnét pompás belátás van a' Városba... "1 A Lonka-, Róma-, Ivánfahegy dombvonulatán az erdőirtáskor sok régészeti lelet került elő. Ősorrszarvú- és mamutcsont, kőszerszám, elvétve római és kelta leletek és bizonytalan eredetű romok.

A Róma-hegy eredeti tulajdonosa Eszterházy Pál herceg, aki egy bizonyos Skossa főbíróval kaposfüredi birtokra cserélte. Eszterházy herceg személye ismert, de a Skossáé nem. Scossa Sándorról van szó (Rábakéthely, 1822-?), aki Sopronban végezte jogi tanulmányait. 1849. augusztus 3-tól a kaposvári járás esküdtje, majd 1850. február 17-én császári-királyi szolgálatba lépett kaposvári járási szolgabíró-segédként. 1853. július 31-től a szigeti járás helyettes főszolgabírája volt. Lakása Kadarkúton volt. 1854. május 1-től 1860ig lett a kaposvári járás segédbírója, azután Vas megyében a felsőkemenesi járás főszolgabírója lett. Zichy

1 Pesty Frigyes: Somogy vármegye helynévtára. Kaposvár, 2001. 156-157. 
Hermann szorgalmas, kielégítő képességű, jó politikai viselkedésű hivatalnoknak minősítette, aki a szolgálatban jó volt, de azonkívül nem tanúsított kielégítő magaviseletet. Ez utóbbihoz Chernel Elek, az új Vas megyei főispáni helytartó hozzáfüzte, hogy magaviselete nem egészen feddhetetlen, mivel feleségétől külön, egy másik nővel él együtt. ${ }^{2}$ A következő tulajdonos Skossa sógora, Würth Adolf, a kaposvári aggápolda gondnoka. Az aggápolda közintézmény 1860-1898 között a Fő utca és az Anna utca sarkán állt. Feltehetően az elemi iskola építkezése miatt 1898-ban átköltözött a Szigetvári utcába. Az aggápolda régi helyén építették fel 1904ben az Anna utcai elemi iskolát. Skossa 1855 körül lett róma-hegyi birtokos, de adóssága miatt elárverezték, s Würth 1862-ben megvette. Rippl-Rónai nem tudott arról, hogy a legkorábbi, 1865-ös telekkönyvi bejegyzés Breil Frigyes magánzót ${ }^{3}$ nevezi meg a Róma-hegyi birtok tulajdonosaként. Würth 1862-68-ig tartó 6 éves tulajdonlására esik ez az adat. A Rippl-Rónai jegyzet következő szereplője Németh Ignác polgármester. „Németh Náci" kétszer volt polgármester: 1878-1881-ig és 1883-1895-ig, s az ő hivatala idején választották meg Kossuth Lajost Kaposvár díszpolgárává. Emiatt és felelőtlen költekezéseiért az ellenzék politikusai hadjáratot indítottak ellene és „számüzték” a városból. A jelen témánkban csak tanácsadóként tűnik fel, mint aki 1868ban rábeszélte Gundy Györgyöt a Róma-hegy megvásárlására. Gundy György (1820-1880) az Osztrák-Magyar Monarchia híres színésze és operaénekese volt. Kaposvár szülötte, a városhoz hü, jótékonyságáért is nevezetes polgára. Apja közismert borbélymester volt. György fia tanítóképzőt végzett, s mint gyakorló kántortanító, tűnt fel különös tehetségü éneklésével. Jelentkezett a Pesti Német Színházba és nagy sikerű énekes színészként utazta be a Monarchiát és a környező országokat. Breslauban, a mai Wroclawban önálló társulata volt. Később a Pesti Német Színház igazgatója lett. 1868-ban vásárolta meg a dombon álló birtokot és a már meglévő földszintes házra emeletet építtetett. A helyi újság is beszámolt arról, hogy „Gundy György, az egykor kitűnő énekes, a pesti német s több külföldi színház neves igazgatója Kaposvárott terjedelmes birtokot vásárolt, melyen egy ízléssel renovált lakot valóban keleti fényüzéssel és ízléssel rendezett be; a helyiség neve: villa Roma. Itt gondolkodik most a derék múvész azon babérokon, melyek annyiszor hulltak lábaihoz, s a művészvilág aranyos napjain, melyek az ő részére a szó teljes értelmében „aranyosak voltak.” Jegyzet: Somogy c. hetilap, 1871. április 18. Tüdőbaja miatt Európa híres üdülőhelyein keresett gyógyulást. Szép parkot alakított ki és a kapura szegezte a Rómavilla címtáblát, talán abban a hitében, hogy a Róma városhoz közeli nyaralások emlékei előtt hódol. A villa homlokzati tetőzetébe kis harangtornyot ácsoltatott, s

2 In: Előadások Vas megye történetéböl. IV. Vas Megyei Levéltár, Szombathely 2004. Söptei Imre: A vármegyei tisztviselöi kar újjászervezése 1861-1962. A hivatali, a politikai és a gazdasági elit Vas megyében. 266. o.

3 Breil Frigyes, a Róma-hegyi fszt.-es ház egykori tulajdonosa 70 éves korában 1910. febr. 9-én halt meg. Felesége Reuter Borbála. Lakása: Kaposvár, Szigetvári u. 47. a csúcsára bádogbuzogányt állíttatott. Emiatt nevezték a villát bádogbuzogányos kastélynak, s a toronyban mindennap délidőben megkongatták a harangot. Gundy hatvanéves korában halt meg. „Gundy György földbirtokos, az elébbi években pedig huzamosabb ideig színigazgató hazánkban és a külföldön, pénteken virradóra (1880. június 4-én) meghalt B.-Pesten. A boldogult egyike volt a legtapintatosabb és szerencsésebb igazgatóknak, s nejével együtt oly terjedelmes, iskolázott s így ünnepelt hang birtokában, mely jelentékeny vagyont szerzett számokra. A színművészet terérőli visszavonulása után is még mindig imádta azt, de - fájdalom - mindig rohamosabban fellépő betegsége meggátolta őt, hogy még egyszer igazgatói pályáján működhessen, melyhez annyi szent emlék, öröm és érdek kötötte. Midőn Somogyba jött, hogy kaposvári rokonai közelében lehessen, itt vett egy terjedelmesebb birtokot, melyre nyári lakot építtetett, s Villa-Rómának nevezte el. Itt élt a művész múltja emlékeinek, rokonai, barátai és ismerősei iránt nagy előzékenységgel és vendégszeretettel. Télre mindig enyhébb éghajlat alá tette át lakását, s közelebb mindannyiunk fájdalmára, kik öt szerettük és tiszteltük, meghalt a fővárosban. Legyen neki könnyű a föld!" 4 A kaposvári Főgimnázium számára jelentős összeget hagyott. ${ }^{5}$ „A villát villává Gundy csinálta illetőleg emeletre vette abból az egyszerü kis házikóból - amit még Skossa építtetett." - mondta Rippl. A Kaposváron 1870. év elején végrehajtott ingatlan kimutatásban úgy szerepel, mint egy emeletes, öt szobás, két konyhás épület. „Érdekes, hogy a Gundy által Róma Villa névre keresztelt épületet a Lonka szőlőhegynél írták össze. Bizonyosnak tűnik, hogy erröl az épületről van szó, mivel Kaposvár határában villa, vagy villaszerü épület kb. az 1890-es évek elejéig csak ez az egy létezett. Egyébként az épület a Lonka- és Róma-hegy határán áll, de a Róma-hegyi részen. Az 1870. év elején tartott összeíráskor az épület 5 szobáját 2 család lakta, összesen 12-en. Érdekes, hogy mindannyian „családtag”-ként vannak felvéve, tehát cseléd nem lakott a villánál." 1880-ban Gundy halála után számos Gundy-rokon között öröklődött a birtok. Az énekes testvérének fiai közül Gundy László, az ipartestület jegyzője „Laczi” névvel kapott Rippl-Rónaitól említést. A Róma-villa Rippl-Rónai szerint Gundy György veje, Breier színész tulajdonába ment át. Ez is új információ, mert Breier színész személye ismeretlen. A következő tulajdonos Brandt József nyugalmazott honvéd alezredes. ${ }^{7}$ Ő lehetett az apja annak a festegető Brandt főhadnagynak, akiről Bernáth Aurél írt „Egy katonafestőnél” címmel. ${ }^{8}$ A tönkrement Brandt alezredestől a halála évében, 1908-ban árverés útján került a villa Dobossy Pál és felesége, Heindlhoffer Angéla tulajdonába. Mi-

\footnotetext{
4 Somogy c. hetilap, 1880 . június 8.

5 Lévai József: A Róma-dombi villa. Somogyi Néplap, 1984. nov. 11.

6 Récsei Balázs: Kaposvár az 1870. év elején végrehajtott népszámlálás, a köz- és magánépületek kimutatása mellékletének tükrében. In: Somogy megye múltjából, 2013. Levéltári évkönyv, 42. 63.I.

7 Brandt József 76 éves korában, 1908. okt. 26-án halt meg. Lakása: Kaposvár, Tallián Gy. u. 19.

8 In: Bernáth Aurél: Így éltünk Pannóniában. 1956. 408-416.
} 
vel Dobossyéknak nem volt szándékában megtartani, 800 korona felárral továbbadták. A művész 1908. júliusban éppen Somogytúron Kunffy Lajos festőmüvésznél nyaralt, amikor levele érkezett Kaposvárról. Testvére, Lajos írta, hogy elárverezték Brandt őrnagy Róma nevezetű villáját, de ha ő ráígér tíz százalékot, még az övé lehet. Az 1906-os Könyves Kálmán Műkiadónál rendezett nagy sikerü budapesti kiállítás jövedelméből megvolt rá a pénz. Kunffy Lajos ismerte a romantikus adottságú ingatlant, s mint földbirtokos jó üzletet látott benne. Rábeszélésére Rippl-Rónai táviratilag intézkedett, hogy öccse eljárjon a szerencsés vásárlás megragadása érdekében. Rippl-Rónai József és neje, Baudrion Lazarette 1908. július 23-án vásárolta meg Dobossy Páléktól a 6 hold, 350 négyszögölnyi birtokot, egész pontosan 14.510.- koronáért. 1910-ben megvette hozzá egy Peterka nevű tulajdonostól a valaha Gundy-birtokhoz tartozó 7,5 hold „külső részt." - Rippl-Rónai nem írt pontos számokat. ${ }^{9}$ Dobossy Pálék Róma-hegyi szomszédok maradtak. A katonatiszt fiuk, Dobossy Elek és Rippl-Rónai nevelt lánya, Paris Anella közt szövődő szerelemből házasság lett. Az ifjabb Dobossy Elek a házasságuk érdekében megtette azt az áldozatot, hogy kilépett a katonaságból azért, hogy a kötelező kaucióval ne terhelje a fizetni nem akaró nevelőapát. Rippl-Rónai ezt a gesztust hálával vette tudomásul, és bizalmába fogadta vejét. ${ }^{10} \mathrm{Az}$ ifjú pár néhány éven át a villában lakott, majd Budapestre költözött.

„Amikor Rippl-Rónai 1908-ban megvásárolta a Róma-villát, elkezdett gazdálkodni. Rövidesen szántóföldet vásárolt a szomszédságban és ugyancsak hamarosan kitudódott, hogy nemigen ért a gazdálkodáshoz, ezt egyébként valójában sohasem vette tudomásul. Nos, a szántóföldet tavasszal, ősszel meg kellett munkálni és erre a munkára a zselicszentpáli Hegedüs Györgyöt ajánlották. Szentpálon több Hegedüs György lakott, Rippl-Rónai barátját Tókának nevezte a falu. Az évek során egész életre terjedő barátság fejlődött ki kettejük között. Hegedüs szinte magáénak tekintette Rippl-Rónai földjeit, úgy, akként müvelte, ahogy szükségesnek látta." 11 A művész halálakor, 1927-ben az alábbi végrendelet szerint jártak el:

\section{„1921.20/V. Végrendelkezem.}

Feleségem: Baudrion Lazarine fogja élvezni - haláláig - az egész vagyonomat. Mindent. Halála után, az egyenes örökösöké lesz mindaz, ami az én nevemen van. Ő rendelkezhetik az ő nevén lévő részröl, ahogy neki tetszik, akár életébe odaadja, elajándékozhatja oly kikötéssel, hogy azt az illető csak az ő halála után kapja birtokába. Megkönnyítésül már itt kijelentem, hogy az első vétel, amelybe a Róma Villa épületével és a nagy kerttel, valamint az utolsó vétel (a Szabadi féle) a feleségem nevén van, tehát feles velem. Ez

9 A Róma-villa adásvételi szerződése. Rippl-Rónai Múzeum adattára 3701.

10 Horváth János: Rippl-Rónai emlékkönyv. Paris Anella visszaemlékezései Rippl-Rónai Józsefről. Kaposvár, 2008. 9-11.

11 Martyn Ferenc: Rippl-Rónai barátja. Somogyi Néplap, 1963. szept. 8. az ami felett korlátlanul rendelkezhetik. Sándor öcsém fiát, aki Sándor hibájából nem viseli a Rónai nevet: Györgyöt, szintén örökségben kell részesiteni olyformán, hogy tizedrészét az egésznek kapja. Természetesen a költségek ráeső részét ő viseli. Müveim elárverezése Budapesten - lehetöleg Ernst Lajosnál menjen végbe. Dr. Petrovics Elek; Nemes Marcell; Lyka Károly; Vaszary János; Dr. Peták Illés ügyvéd, Dr. Lázár Béla készítsék elö az aukciót. A befolyt összegek kamatait feleségem élvezze. Rippl-Rónai József Dr. Pogány Kálmán Urbach József Medgyessy Ferenc'12

Lazarine 20 évvel Rippl-Rónai halála után, 1947ben halt meg. Végrendelete szerint a saját tulajdonát dr. Martyn Róbertnek adományozta. ${ }^{13}$ Anellát kihagyta az örökségből. Rippl-Rónai József után részesült a müvész Lajos nevü öccsének fia, dr. Rónai Gusztáv. $A z$ ő részét dr. Martyn Róbert később megvásárolta. Az 1950-es években elrendelt tsz-esítés után a 6710/1. sz. alatti birtok 6 kh 759 négyszögölre csökkent, vagyis a parkosított és beépített részre. Abból történt a Róma-villa és a szükebb környékének, 3 kh 1074 négyszögölnek az eladása az állam részére 1970. október 28-án. ${ }^{14}$ A Róma-villa müemléki felújításra került, és 1978. augusztus 20-án nyílt meg Rippl-Rónai József Emlékmúzeumként.

\section{Az otthonteremtő Lazarine}

„Zord fejü asszony. Kemény vonásaiból pillanatokig még a francia jakobinusnőt is kiérzem. De mintha itthon is található volna ez a típus, kisebb városokban. Mit szenvedhetett ő itt a hegyen, némán, féltve ezt a hiú embert, aki csak fél életét élte itthon, felét pedig a pesti szalonokban, a szépasszonyok körül. Mi tartotta össze öket? A küzdelmes fiatal koruk emléke? Amikor még támasza is lehetett? Úgy érzem, még most is vasmarokkal fogja, amikor már haldoklik. Miben van az ereje, ha se szépség, se szellem nem tehette a magáét? A kemény vidéki nőt érzem benne, aki fogához veri a garast, és tréfát nem ismer, ha a vagyon vagy a család körül forog a dolog.

A munkába ölte itt magát, kacsát, ludat, disznót nevelt, müveltette a földeket, s várta haza az urát. Társasága alig volt, jóformán csak az a pár rokon, aki néha vette a fáradtságot, s feljött ide a hegyre. Törve beszélte a magyart, s így még hontalannak is érezhette magát. Gyereke nem volt, csak egy árván maradt rokon leánykát, Anellát hozta el magával hazulról." - ezt a nagyszerű személyleírást Bernáth Aurél írta 1927-ben Rippl-Rónai feleségéről, aki 61 éves elmúlt már akkor.

„Lazarett”-nek a régi időkben a vesztegzár alá kényszerült hajót, azután a katonai kórházakat nevezték. Rippl-Rónai Lazarinja a gondoskodás, a szerető, hüséges szolgálat jegyében élt 81 évet. Leánykori neve szerint Lazarette Baudrion 1866. június 15-én született a franciaországi Burgundia Marly nevű kis falujában.

12 Gépelt másolat a RRM adattárában.

13 Másolat a végrendeletröl. RRM adattára 2629.

14 Másolat az adásvételi szerződésröl. Rippl-Rónai Múzeum adattára $5178-93$ 


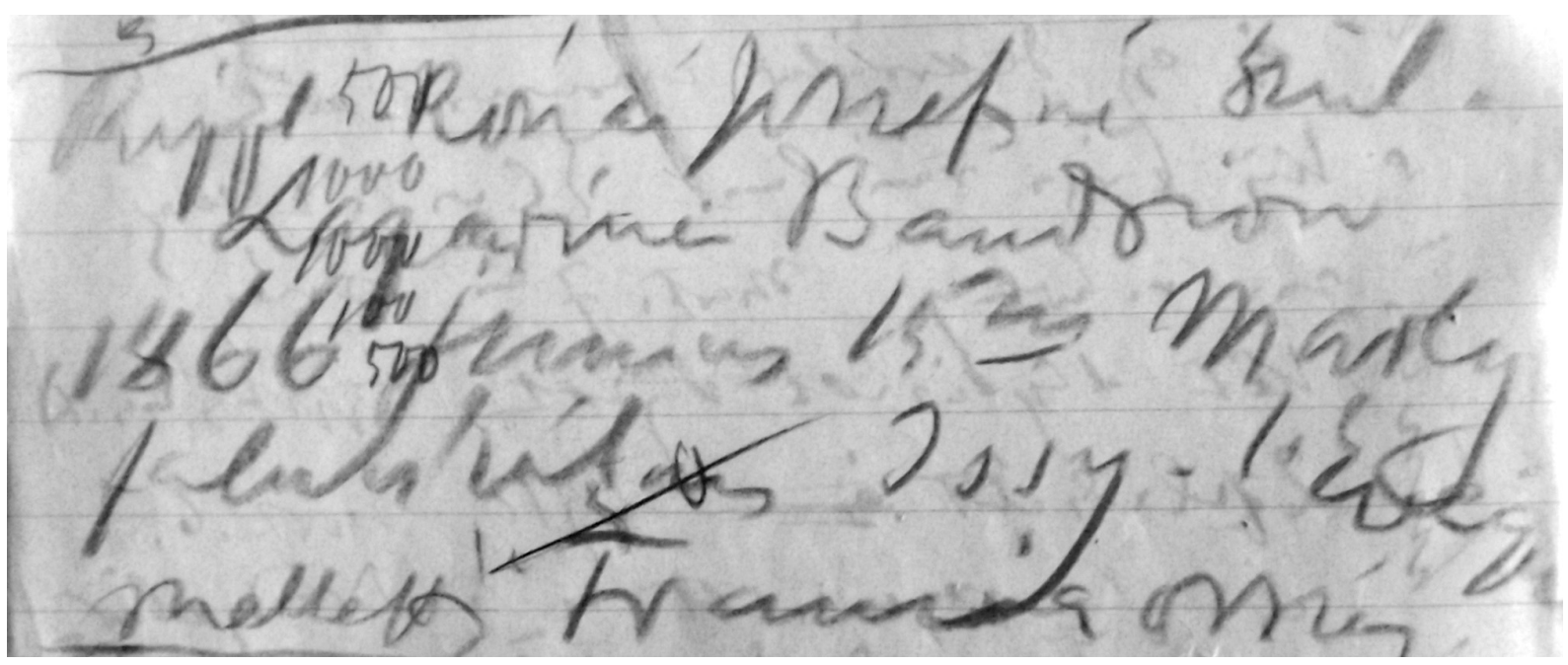

4. ábra. Rippl-Rónai József kézírása Lazarine születési adatairól

A népes Baudrion család Marlyból Issy-L'Éveque-be ${ }^{15}$ költözött (4. ábra). Párizsban a Julian Akadémián modellként dolgozott. Rippl-Rónai mint Munkácsy-tanítvány 1888-ban látogatta az akadémiát és lehetséges, hogy ott le is rajzolta az ismeretlen, szomorú szemü, karcsú derekú lányt. Személyes ismerkedésük is abban az évben történt egy Neuilly-ben megtartott népvásár forgatagában. A családi szóbeszéd őrizte meg az esetet, amikor a múvész a színesen nyüzsgő forgatagban meglátta Lazarette-t. Vele volt a húga, Claudine. A művész az emlékhez többször visszatérve a „Carussel” témában, kis kerámia képen örökítette meg a látványt. Szíve hölgye festett falovon, kék ruhában, barna kalapban a csengő, zengő karusszel körforgásával lovagolt az életébe. Vajon milyen volt az a nő, milyennek látta őt az idegen, magányos fiatalember, aki akkor még kereste önmagát, kutatta helyét a művészetben és az életben? A nem sokkal későbbi fényképen egy aggódó arcú lányt látunk, akinek hoszszú, barna haja úgy van feltűzve, mint a japán gésáké. Erős jellemet kifejező, egyenes vonalú szemöldök alatti nagy szemek kedvesen félénken vannak lesütve. Férfiasan határozott, széles orra és szintén széles és hullámzó a szája. Az alsó ajka kislányosan bújik a felső alatt, amely bájos karaktervonása sok francia nőnek. Lazarine csendes, visszahúzódó, az otthon körüli munkában serény asszony volt, és bensőjében határozott, egyéni stílussal bírt. A festő szemével érdekes karakterü, vonzó jelenség lehetett. Az idő múlásával elveszítette hamvas fiatalságát, elnehezült, a darázsderék eltűnt. Rippl-Rónai kevés arcképet festett róla, de vallomással felérő a „Kalitkás nő” (1892) című főmü. Az életnagyságú alkotáshoz Lazarine állt modellt. Személyéről ez a kép adja a legtöbb információt. A bizonyságát, hogy Lazarinet látjuk a képen, megerősíti a híres kép előzeteseként festett „Kalitkás hölgy. Vázlat” (1892). Ott a kisebb méretü, szükebb terü képen az arc profilja nin-

15 Rippl-Rónai József jegyzetfüzetében szereplő autográf beírás szerint. MNG Adattára. csen idealizálva, s így könnyebben ráismerhettünk a modellre. A két képet együtt látva egy szerelmi ihletésü eszményítési folyamat tanúi vagyunk. A szerelemben összetalálkozott életközösség a müvészetért való áldozatos munkában vált szétválaszthatatlanná. Kölcsönösen „Munikának” becézték egymást (5-6. ábra).

Thadée Natanson így figyelt fel Rippl-Rónai élettársára: „A látogatók felfedeztek nála egy komoly aszszonyt, fekete szalagokkal a hajában, aki rendszerint eltünt láttunkra. Nagyon sokáig még a hangját sem ismerték. Végig azt hittük volna, hogy honfitársa a rejtélyes barátnö, ha az udvarias Lazarine egy szép nap, de csak évek múltán s egész véletlenül ki nem kottyantja, azt a burgundi falut, ahol annak rendje és módja szerint megszületett."16

Lazarine nemcsak modell és élettárs, hanem alkotótárs is, iparmüvész volt, a Rippl-Rónai által tervezett hímzések kivitelezője. A francia nők gobelinezését, mint hagyományos kézimunkát gyakorolta. Esztergált farudakból szerkesztett hímzőkeretbe szorított vásznon öltögette a színes fonalat a rárajzolt sablon szerint. Egymáshoz simuló lapos öltéseket és hasított öltéseket alkalmazott. Ha a tervezett textil nagyobb volt, mint a feszítőkeret, akkor középről minden irányba kellett araszolni tovább a szélekig. Az „Ideálizmus és reálizmus” című kárpitot 1895-ben „egy rosszul égő mécs világánál" Neuillyben készítette selyemszállal. Ez a mü a párizsi Szalonban több más hímzéssel együtt kiállítási díjat nyert. 1906-ban egy hímzett kályhaellenzővel együtt szerepelt a milánói nemzetközi kiállításon. A magyar pavilont elpusztító tragikus tűzben mindkettő mü elégett. Szerencsésen fennmaradt az Andrássyebédlő emblémájaként ismert gobelin, a „Vörösruhás nő" (1898). Annál a munkánál Lazarine először használt hímzőanyagként gyapjúfonalat. Úgy tapasztalta, hogy a selyemhímzések idővel erősen megkoptak, elhalványodtak. A gyapjúfonal puha és rusztikus anyaga

16 Thadée Natanson . Fordította és közli: Cs. Szabó László: RipplRónai és Natanson. Magyar Művészet, 1949. 1. sz. 32. 


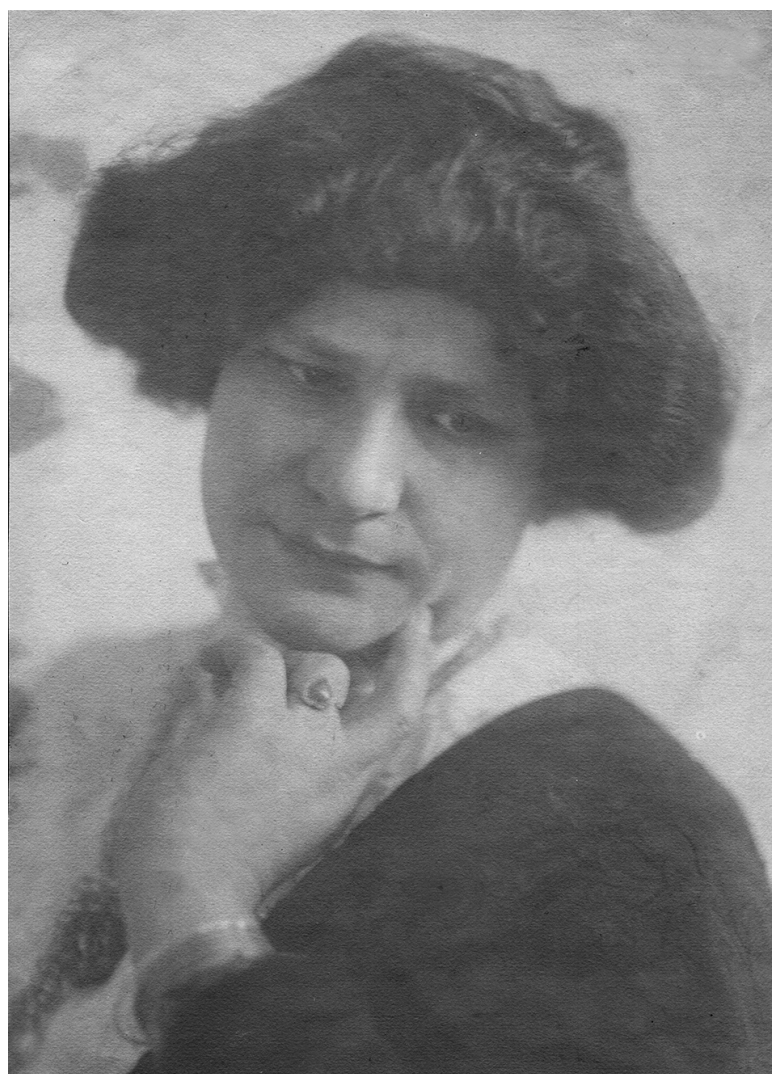

5. ábra. Lazarine fényképe 1899 k.

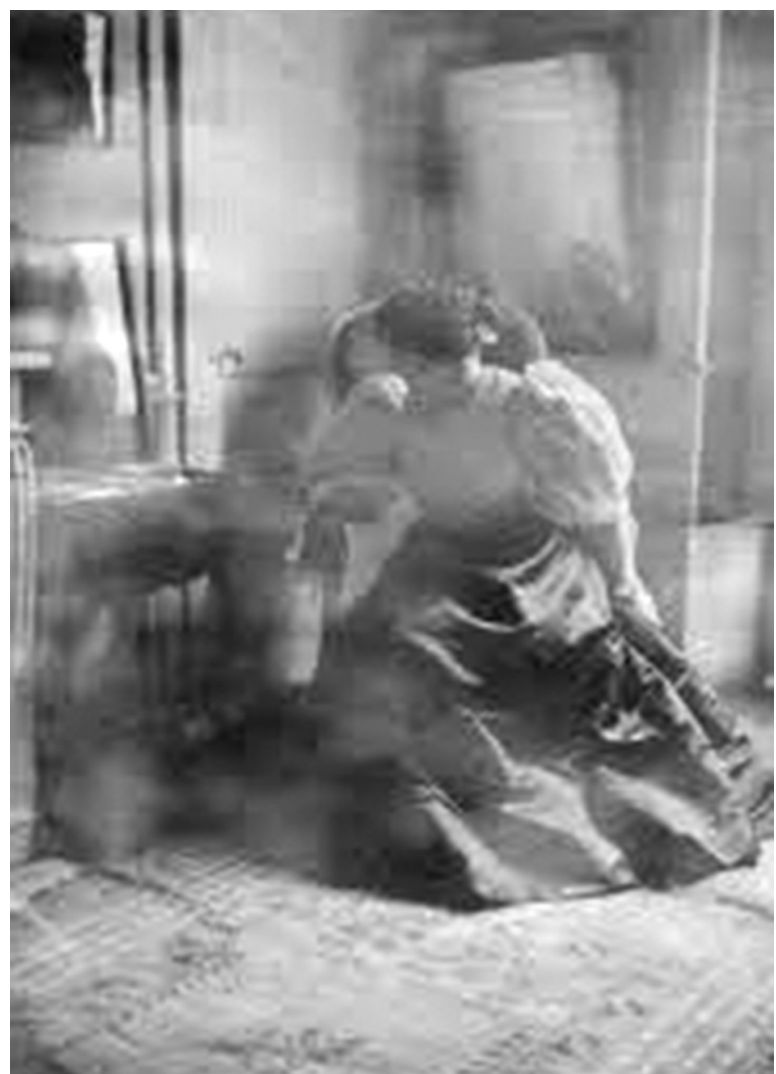

6. ábra. Lazarine Neuillyben. 1899.

erőteljesebb dekorativitást, a színek élénkebb érvényesülését tette lehetővé. Az Andrássy-ebédlőhöz készült még egy három négyzetméteres, virágmintás paraván és egy 30 méter hosszú, mennyezetet keretező fríz, amelynek kivitelezése óriási munka lehetett. Ahhoz besegített Claudine is. Az 1900-i párizsi világkiállítás zsűrije a Rippl-Rónai József \& Lazarette Baudrion hímzésterveknek ezüstérmet ítélt, s ezáltal Lazarine elismert iparművésszé lett avatva. A közös siker nyomán Rippl-Rónai még Párizsból tudatta Ödön öccsével, ha őt bármi érné, Lazarine lesz az örököse.

„Most ez idő szerint itt a kanyaró és tífusz kaszabolja le az embereket, uralkodik, meglehet, hogy hozzám is elnéz, és elvisz magával. Szeretném, ha legalább Te tudnád, mik egyszer s mindenkorra terveim Lazarine-ra nézve. Szeretném, ha kívánságomat szigorúan betartanátok, ti. ha pénzem a 2000 Ft-ot meghaladná, kívánságom az lenne, hogy a „négyes” kamatokat egészben ő élvezze, természetesen az Andrássy-pénzt is beleértem. Ha pénzem nem haladná meg a 2000 Ft-ot, úgy az egészet neki szántam. Bútorzatomat eo ipso az ő tulajdonának tartsátok. Itt levő képeimmel ő rendelkezzék, elárverezheti, vagy magának megtarthatja. Máskülönben pedig azt szeretném, hogy édesanyánk körül lenne, természetesen egymás közti megállapodás szerint. Minden tekintetben segítségére legyetek, és mint testvért vagy nővért vegyétek. Megérdemli."17

17 Rippl-Rónai József levele Ödön öccsének. Párizs, 1897.

Rippl-Rónai nem részletezi öccsének a „megérdemli” szó tartalmát, s nem tudjuk, hogy miért nem akart házasságot kötni.

1902-ben Rippl-Rónai végleg hazatért, s egy parasztházat vásárolt a kaposvári Fő utca végén. Ez a legendás ház már nincs a föld színén, de a művész nem titkolta, hogy Lazarine keze munkája tette kellemes otthonná. „A kerti munkálatok most a legszebbek, legérdekesebbek, t.i. mi tavasszal is akarunk látni tüzes szép virágokat, pl. tulipánt, jázmint, nárciszt, ibolyát, árvácskát, nefelejcset. Ezek köszöntenek be legelöször. Már nagy részben intézkedtünk is. Majd meglátod, hogy mily kedves lesz, amilyen rég nem volt, kis házunk és a két kis kert. Igazi magyar házikó igazi magyar kertben elöl, hátul. Várjuk most - Papával együtt az elültetendő cserjéket stb. dolgokat, szöllőt is."18

"Minden a mit a kis „fehér házban” találtam gyönyörüséget okozott. Már a kertbe lépésnél a szépen ápolt zöld kert terített szép asztal fogadott és tárta ki ölelkező karjait. A szobák mind felfrissülve színben és elrendezésben várták gazdájukat. Igazán mondhatom, hogy Lázárin izléses elrendezése a legraffináltabb müvészt is kielégítené. Nem hiszem hogy XIII. Leo pápa születése szobája nemesen egyszerübb lett volna."19

18 Rippl-Rónai József levele Ödön öccsének. 1903. okt. 29. Kaposvár. MNG Adattár

19 Rippl-Rónai József levele Ödön öccsének. 1904. aug. 16. Kaposvár, Fő u. 58/a. MNG Adattár 
Tizenkét éves párizsi és hatéves magyarországi együttélés után 1906-ban Budapesten a családot kizárva kötöttek házasságot. Talán van egy valószínű magyarázat arra, hogy miért nem korábban és miért éppen akkor történt meg a házasságkötés. A művész édesanyja, mint a kisváros bigott erkölcsi szokásainak híve, katolikus kisleányok magánórás illemtanára, nem tudott szerető viszonyban lenni a fiával vadházasságban élő idegen nővel. A családban mindenek fölött álló, szeretett Mamának kíméletet adott a fia azzal, hogy kivárta a házasságkötés megfelelő idejét. Egyik Rippl-Rónai kép beszédesen vall a két asszony közti távolságról. A „Karácsony” (1903-04 között) című festményen csak ők ketten szerepelnek. Feketébe burkolt, egymástól teljesen elszigetelt, elforduló alakjuk a karácsonyfa mellett sem mutat barátságos közeledést. Rippl-Rónai édesanyja 1905. december 29-én halt meg. A családi szomorúságot hamarosan nagy öröm követi azzal, hogy 1906. február 1-jén a budapesti Könyves Kálmán Szalonban rendezett kiállítással Rippl-Rónai befutott festő lett. A sorsfordító kiállítás rendezését és az árverezést egy Pesten bérelt lakásból irányította a müvész. Vele lehetett Lazarine is. „Édes Ödönöm. Végre a nagy rumli megszünt és pedig igen szép eredménynyel: a kiállítás is és az áukczió is. Majdnem egyformán eredményezett, még nincs meg az összeszámolás, de azt hiszem elment 400 kép 45 - 46.000 koronáért. Ebböl természetesen nagyon nagy rész - egyrészt 33 és $1 / 3 \%$, másrészt pedig $20 \%$ Könyves Kálmánnak jut. Mindenesetre nagyon nagy dolgot oldottunk meg rövid egy hónap alatt. Egész Budapest mozgásban volt és fö tárgy volt a társalgások alkalmával a Rippl-Rónai kiállitás és aukció.... Andrássy-úti (38 sz. IV 8.) lakásomat május 8-ig megtartom. Mialatt azonban lemegyek hozzád is és Kaposvárra is. - Mily boldogság lenne most aranyos kis Anyánkat szíven csókolni. Öt akit ez a dolog oly jól érintett volna. Békesség poraira! Lázárine jól van, jövő héten ő is haza megy. Kapunk egy szép hím pávát és a kert is már megköveteli a gazdáit.. Isten veled." 20 A művész erkölcsi érzéke fejeződött ki abban, hogy küzdelmeiben hű élettársát május 7-én Budapesten nőül vette. Gyermekük nem született. Lazarine árván maradt unokahúgát, Anette Parist, a művész által adott becenevén ismert Anellát 1910-ben hozták el IssyL’Éveque-ből és saját gyermekként nevelték fel. „...Mint fiatalasszony, ha nem is kimondottan szép, de csinos megnyerő valaki volt. Kedves volt az arca és egész lénye szimpatikus" - állapította meg a nevelőanyjáról, Lazarine-ról Paris Anella.

Lazarine nagyon nehezen tanult meg magyarul beszélni. A franciául tudó Piatsek Ferenc, a Rippl-képek Piacsek bácsija igyekezett ebben a segítségére lenni. A kettőjük napi rendszerü társalgásakor festette róluk Rippl-Rónai az enteriőr korszak képeit. 1908-tól Lazarine volt, aki felügyelte a tízholdas Róma-hegyi birtokot, amelyet egy rokon, Hegedűs György (alias Tóka) felesben múvelt. Három-négy tagú személyzet, illetve cselédség felett rendelkezett. Miután a szakács-

20 Rippl-Rónai József levele Ödön öccsének. Budapest, 1906. március 7. MNG Adattár Itsz.: 20408/1979/14/b; MTA MKCS-C-36/535 nővel megbeszélte az aznapi ebédet, a Róma-villa virágos kertjében, konyhakertjében és a baromfiudvarban tevékenykedett. A ház ura a rendszeres, egész napos alkotómunka közben ebédszünetet tartott, és délután négykor csatlakozott hozzá. Karácsonykor a zongorán álló, feldíszített fenyőfa fölé a francia szokást tartva fagyöngyöt akasztott. Konyhájának jó hírét, a magyarosfranciás ízekben bővelkedő szakácstehetségét a Nyugat folyóirat írói terjesztették. Az állatfarmról sült birkahús, kacsa, pulyka, csirke került az asztalra. Salátakeverékeit gyakran a környező vidék vadon termett növényeiből gyüjtögette össze. A gyomnövények közül sokféle, másmás zamatú apró leveleket tépkedett. Konyhaművészetét még a gyermekkorból hozta, s a festővel töltött párizsi szegénység idején találékonyan alkalmazta. A húsz évvel korábbi párizsi életükben legfeljebb csak álmodozhattak a Róma-villa paradicsomi gazdagságáról (7. ábra). Valószínü, hogy 1899-ben, Aristide Maillol Banyuls nevű szülőfalujában vendégeskedve született meg a vidéki életidill eszméje, keresése. Az álmot a közös sors váltotta valóra. A birtok mérete akkora volt, amely nem haladta meg erőiket. Lazarine naponta a kertjük virágaiból minden szoba asztalán álló vázába rakott egy-egy frissen vágott csokrot. A karóra futó rózsáit nagy gonddal nevelte. Az asszony született otthonteremtő, lakberendező tehetsége nyomán vált programszerűvé Rippl-Rónai otthonkultusza. Nehezen viselte az 1917-től majdnem tíz évig húzódó Zorka-ügyet. Abban az időben a művész „darázsfészeknek" nevezte a villát. Fájhatott az asszonynak, hogy férje oldalán már nem ő, hanem egy fiatal nő díszeleg a budapesti kávéházi társaságban.

Rippl-Rónai József halálát követően az özvegy húsz évig élt egyedül. Gazdálkodásból és férje festményeinek eladásából igyekezett megélni. 1934-ben a művészi hagyatékból 53 képet bocsátott árverésre, de csak 27 talált vevőre. Magányát és kiszolgáltatottságát kihasználták, s a Rippl-Rónai képek javától megfosztották. Megtörtént, hogy miután behálózta őt Völgyessy Ferenc mügyűjtő, egy szekérnyi RipplRónai képet pakolt fel magának a Róma-villában. Fizetségül Lazarine elé tett egy alku nélküli pénzöszszeget. Az asszony hiába tiltakozott és sírva kiáltozott utána, Völgyessy elhajtott a fogatán. ${ }^{21}$ Nevelt fia, dr. Martyn Róbert írta Paris Anellának: „Völgyessy22. Ami a Völgyessy ügyet illeti azt én megmondtam Lazarine néninek, hogy őt a Völgyessy kifosztja, sőt ezt megmondtam, helyesebben megírtam Völgyessynek is, mire igen hosszú levélben válaszolt, hogy ő viszszaad mindent, de Lazarine néni nem fogadja vissza a képeket. Szerintem nem 10-15 darabot, hanem 50-60 drb képet és rajzot is elvitt. De én már nem szólok bele, én ezt többször is megmondtam Lazarine néninek. Lazarine azt tesz amit akar. Még talán az érne valamit, ha Petrovics igazgató úr felvilágosítaná, bár talán ez sem ér semmit."23

21 Dr. Martyn Róbert szóbeli elmondása.

22 Dr. Völgyessy Ferenc főorvos, mügyüjtő. In: Takács Gábor: Műgyűjtők Magyarországon a 18. század végétől a 21. század elejéig. Budapest, 2012. 481-482.

23 Dr. Martyn Róbert levele Dobossyné Paris Anellának. Kolozsvár, 1942. XII. 20. RRM adattár 2635 


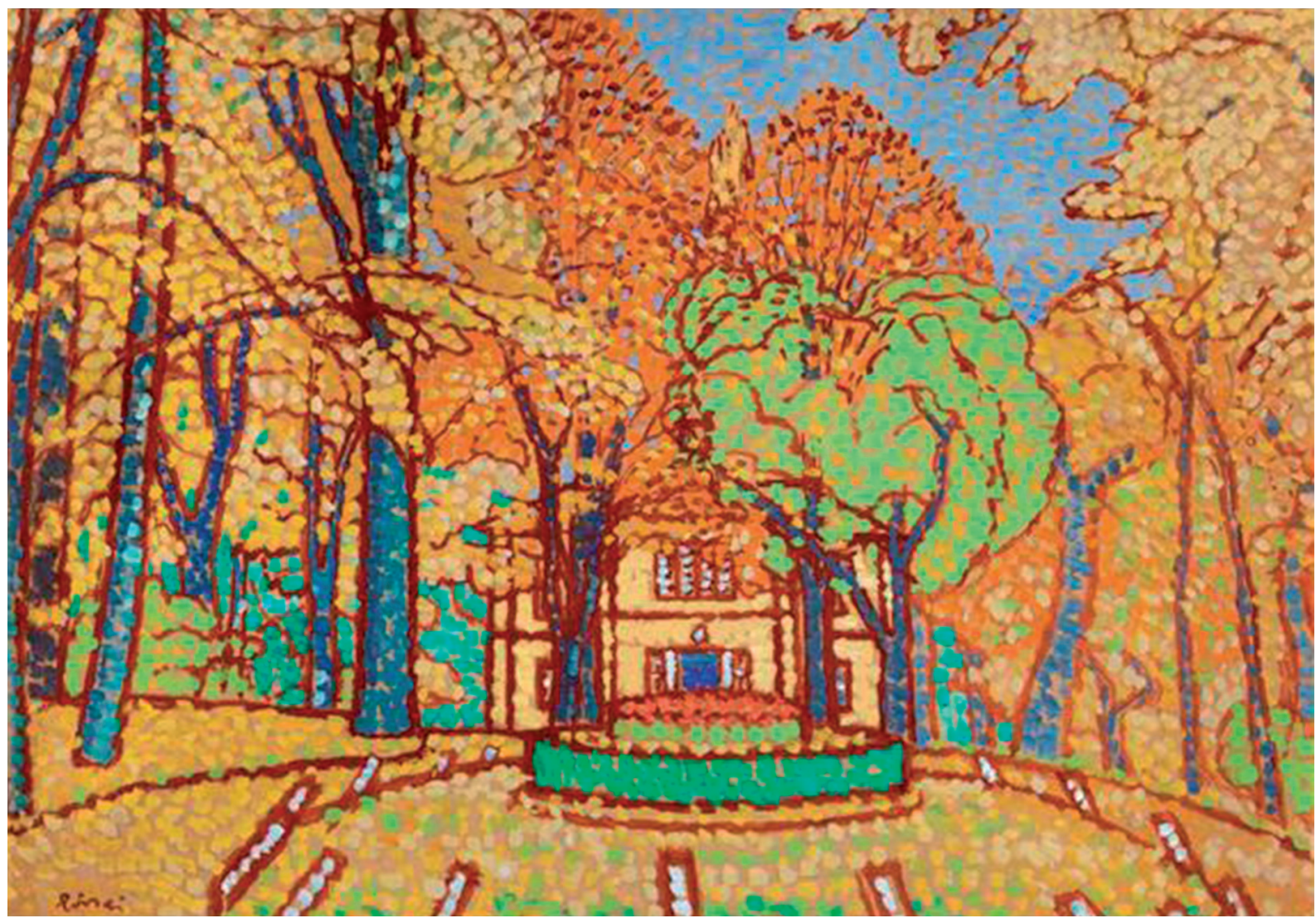

7. ábra. A Róma-villa ősszel, 1914 körül

Erre a levélre írta rá Anella a következő megjegyzést: „Már előzőleg 31-ben v. 32-ben, Lazarine néni rajtunk kereste ezeket a képeket - ugyanis 27-töl 31-ig nálunk voltak raktározva - a személyzeti szobánkban, de sajnos a sok intrika és L. néni ellenséges viselkedése miatt kénytelenek voltunk az Americain - brit longtraisine (?) raktárába vitetni az egész anyagot. Valamivel később L.n. feljelentette férjemet az ügyészségen a legképtelenebb vádakkal - de az ügyészség elejtette a vádat. Ettől az időtől kezdve nem érintkeztünk. Csak 42-ben üzent értem L. néni és attól fogva haláláig évente 3-4 szer meglátogattam."

A feljelentést megelőzően egy groteszk szenzációt kapott fel a budapesti sajtó. Ugyanis Lazarine a könyveit lapozva rátalált egy nagy összegű bankbetétet igazoló cédulára. Elhíresztelte, hogy „Jó ember volt Józsi, a halála után sem feledkezett meg rólam s jelentkezett, hogy segítsen rajtam..."24 Az Est sorozatban tudósított róla ${ }^{25}$ : „Különösen müvészkörökben keltett nagy feltűnést $A z$ Est tegnapi cikke, amely elmondotta, hogy Rippl-Rónai József szelleme milyen csodálatos módon vezette eltűnt örökségének nyomára özvegyét." Amikor közölte a bank, hogy nincsen semmiféle pénz már a cédula

24 Az Est. 1933. 96.sz. 1933. ápr. 29. 5. Göllner Aladár: Rippl-Rónai József szelleme eltűnt öröksége nyomára vezette özvegyét.

25 Rippl-Rónainé és Dobossy Elek nyilatkozik a mester hagyatékáról. Az Est. 97. sz. 1933. ápr. 30. 5. mögött, Lazarine feljelentette Anelláékat. Anella férje, Dobossy Elek nyilatkozatot tett az újságban: „Engem a rendőrségen arra nézve hallgattak ki tanuképpen, hogy tudok-e az állítólagos valóra betétröl. Megmondtam, hogy az elökerült cédula alapján keresett betét csak a háború elötti koronabetétre vonatkozhatik, melyet a müvész még a háború első éveiben megállapithatóan sajátmaga vett fel és költött el. Ezt a bizonyos cédulát azért sem írhatta a megboldogult röviddel a halála elött, mert három-négy utolsó hetében alig tudott már magáról, írásról akkor szó sem lehetett. Ezt orvosai, rokonai és barátai, akik akkor körülötte voltak, jól tudják. A müvész legális végrendelete a kaposvári hagyatéki bíróságnál fekszik. Ebben Kereskedelmi bankbetétjéröl szó sincs. A nyomozás során egyelöre előkerült pengőbetétröl a megboldogult nem tudott, nem is tudhatott: ezt az összeget én szereztem képeladásokból, az özvegynek én tettem be az ö nevére a Kereskedelmi Bankba. Ezt az összeget, amelyet később kamatdifferencia miatt a Magyar Általános Takarékba vittük át, közös egyetértésben a kaposvári kis gazdaság fenntartására és háztartására fordítottuk. Ezekről rendes feljegyzéseink vannak. Ezt a betétkönyvet egyébként évek óta az özvegy kezeli és él a pénzböl ma is. Úgy látszik ő ugyanezt az összeget a „szellemek” segítségével mégegyszer szeretné megkapni. - Az egész „hagyaték” keresés csak egy nagyrészt ideges képzelet rémlátásai, vagy bosszú müve. Az özvegy ma is birtokolja 


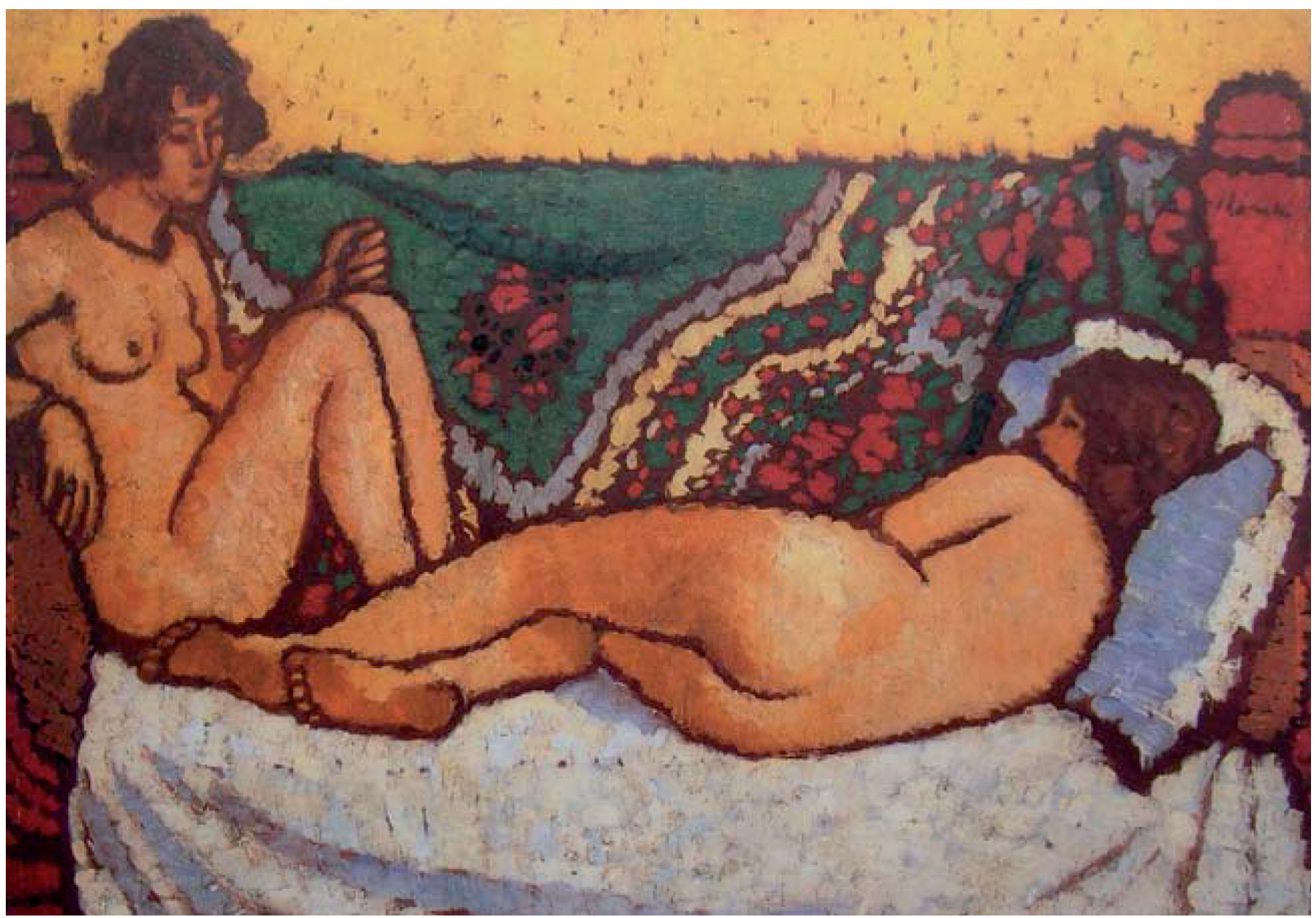

8. ábra. Aktok. Fenella és Anella díványon. Két meztelen leány vörös díványon, 1911

a tényleges ingatlan- és képhagyatékot. - Az özvegy által előadott fantazmagóriák annyira komikusak és ellenkeznek a közismert és bizonyitható tényekkel, hogy mindezt a tegnapi cikk után végre kénytelenkelletlen a nyilvánosság előtt is meg kell mondani."

Lazarine asszony róma-hegyi gazdálkodásának aprólékos gonddal megőrzött számlái alapján az évi gabona- és bortermés és hízott sertés eladásából élt. A villa épület viharok tépázta tetőzetét gyakran kellett javíttatnia. Az összes ebadószámlát megtartotta. ${ }^{26}$ A házadó megfizetése esetenként nehézségekbe ütközött. Az utolsó éveiben, amíg bírta, évente egy sertést hizlalt. Rendszeres látogatója volt Rippl-Rónai Ödön Szabó Katicája. A müterem épület másik felében lakott a vincellér. A sok szőlőművelő közül az egyik Rippl-Rónai József elemi iskolás barátja, egy I. világháborús történeteket mesélő veterán, Horváth Károly, akit a városban Kutyás Károlyként ismertek. ${ }^{27}$ Fiatal falusi lányokat alkalmazott cselédnek. Az idős asszony betegségét dr. Martyn Róbert kezelte, ezért őt, mint nevelt fiát tette meg örökösévé. 83 éves korában, 1947. július 7-én halt meg. Férjével közös sírban nyugszik a Keleti temetőben.

26 Özv. Rippl-Rónai Józsefné gazdálkodási számlái. Rippl-Rónai Múzeum adattára.

27 Lévai József György: Kaposvári történetek

\section{Rippl-Rónai 50 rajzáról és Fenelláról, a dalénekes aktmodellről $^{28}$}

Rippl-Rónai művészetének titka, eszenciája a rajz. A modern magyar festőink közül az ő művészete áll legszorosabb viszonyban a rajzolással. A Müncheni Akadémián három évig tanulta ezt a mesterségét, pedig feleannyit volt szokás. Az ő számára azért alakult így, mert a festészeti szakot a drága tandíj miatt nem tudta felvenni. Mégis ebből a hátrányából származik a későbbiekben kamatozó haszna. A Munkácsy-stílus utánzása bénító erővel nehezedett rá, amely alól a rajzi kultúrája segített szabadulni. Ő maga „búvárkodásnak” nevezte azt, amit mi modern múvészeti kísérletezésnek nevezünk. A többféle stílus korszakkal osztott művészetében a rajzok elemzése segíti a belső összefüggéseket felismerni, az egész életmü hosszát átívelő logikusan kapcsolódó láncolatot megtalálni. A 3800 darabos életmű kétharmadát teszik ki a rajzok. Vannak tanulmányok, vázlatok és önálló grafikák. Rippl sajátos módon tanulmányának nevezte minden olyan alkotását, amelyben a figyelmét valami újdonság keresése kötötte le. Amikor Párizs után visszajött Kaposvárra, a kisvárosi karaktereket tanulmányozta. Nem olyan célzattal, amint az akadémiai tanulmányrajzainál tette. Már fölötte állt a

28 A Róma-villa Látogatóközpont 2016-i kiállításának megnyitója 
technikai tudásnak és a párizsi küzdelem és megpróbáltatás szellemi magasáról tekintett szülővárosának gyermekkorból ismert és újra felfedezett társadalmára. A kaposvári karakterábrázolások nem részletbe menők, hanem tipizálók. A rajzok, tanulmányok egyszerűsítő vonalai általános emberi tulajdonságok után kutattak. Ebben a szellemben folytatott fejlődési úton jutott el a legmodernebb rajzaihoz, azokhoz, amelyeket „RipplRónai J. ötven rajza" címmel 1913-ban mappában jelentetett meg a Könyves Kálmán Műkiadó.

Az album úgynevezett klisényomatokból áll. Savval maratott fémlemezről nyomtatták, de ritkaságuk miatt felértékelődtek és bejutottak a műkereskedelembe. Az eredeti tusrajzokból néhány a Magyar Nemzeti Galéria tulajdonába került, és néhány lap jutott Ödön testvér gyűjteményével a Rippl-Rónai Múzeumba. Az 50 rajzot Rippl-Rónai önálló grafikai műveknek szánta. Nem vázlatnak, nem tanulmánynak, hanem bekeretezhető, falra rakható, múélvezetre megérlelt képeknek. A rajzok többsége a Róma-villában készült. Erre utalnak az egykori háziállatokról, Heppy és Vix kutyáról, kacsákról és disznóölésről készült rajzok. Az ismerős modellek, Lazarine és Anella ábrázolása mellett feltűnik egy új női alak, akit egy új múzsának is tarthatunk.

A művész nevelt lányától, Anellától tudjuk, hogy 1910-ben egy feltűnő vendég állított be a Róma-villába. Egy angol-amerikai cigány leány Párizsból jött előzetes bejelentés nélkül. A jövetelnek röpke előzménye volt. Ugyanabban az évben, 1910-ben RipplRónai elhozta magához saját gyermeke gyanánt Franciaországból Lazarine unokahúgát, az édesanyját elvesztett Anellát Kaposvárra. A párizsi átutazás során, egy hotelben megszállva figyeltek fel egy szép női énekhangra. A szomszédos szobából hallatszott, hogy valaki rossz magyarsággal, gitárkísérettel énekeli Rippl-Rónai kedvelt nótáját a „Csak egy kislány van a világon” címü dalt. A szívhez szóló hatás után kutatva benyitottak hozzá. A megszólított énekesnő Fenella Lowell néven mutatkozott be. Elmondta, hogy apja amerikai cigány, anyja angol úrinő. Londonban élt és egészen fiatal korától különálló életet él. Párizsban modellje volt az akadémián tanuló magyar festőnövendékeknek, s tőlük tanult magyar dalokat. Francia, angol, olasz, spanyol, német és orosz dalokat is énekelt. A szívélyes ismerkedés után „egy igen értelmes, müvelt nőt fedeztek fel benne. Nemcsak énekelni tanult - de zongorázni is szépen és jól tudott”. ${ }^{29}$ A házaspár azzal köszönt el tőle, hogy ha Magyarországon jár, keresse fel őket. A futó ismeretség alapján, néhány hónap múlva Fenella megjött Kaposvárra. A meglepetés okozta feszengést azonnal feloldotta. Énekelt, zongorázott, gitározott, modellt állt, s a Montmartre múvész negyedének felszabadult hangulatával villanyozta fel a Róma-villa lakóit. Feltűnően egyéni stílusban, maga tervezte cigányos ruhákat viselt. Arca nem volt szép. Fejét dús, szőke, göndör haj koronázta, melyet szalaggal tornyozott fel. Extrémitása egészen elbűvölte Rippl-Rónait. - „Ilyen szép és tökéletes aktot sem elöt-

29 Horváth János: Rippl-Rónai emlékkönyv. Paris Anella visszaemlékezései Rippl-Rónai Józsefről. Kaposvár, 2008. 30. te, sem utána nem látott" - mondta Anella. Az albumba került ötven rajz jelentős része Fenelláról készült ruhában és aktban. Rippl-Rónai „kukoricás korszakos” festészete sokat nyert Fenella aktjával.

„A magyar müvészetben az emberi alak, az akt tanulmányozása, ugyanazt a magasrangú szerepet játssza, mint minden európai müvészetben - írja Lyka Károly az 1926-ban a Műcsarnokban megrendezett aktkiállítás albumában, amely kiállításon Rippl-Rónai érthetetlenül nem szerepelt. ${ }^{30}$ Lyka így folytatja: „Változhatnak a festészet és szobrászat irányai, változhatik a müvészeti felfogás, az akt mégsem veszt jelentőségéből, mert egyrészt az előkészitő tanulmány legfontosabb tárgya, másrészt a telivér müvészeti problémáknak szinte kimeríthetetlen sorát kínálja s ezzel próbaköve lett a tudásnak, élesztője a törekvéseknek.” A „kukoricás” stílusú festmények témakörében nélkülözhetetlen lépés volt a női akt motívum bevezetése. Az Ernst Múzeum üvegablakánál is hasznosult. A nehezen szerezhető aktmodell Kaposváron problémát okozott Rippl-Rónainak. Budapesten a Haris közi rajziskolában jobban tudott e célból intézkedni. Az 50 rajzból néhányat a szabadiskolában alkalmazott modellekről készítette.

Fenella tehát Rippl-Rónai múzsája lett. A vele folytatott munka nem festéssel, hanem rajzolással kezdődött. Egy-egy rajzon a művész lelkesült szavai olvashatók: "Óh luce di Quest anime Donizetti” - azaz „Ó dicsőség ennek a donizetti-szerü léleknek.” Ez a szöveg dalidézet lehet. Másik rajzon a zongora mellett álló akt fölé ezt írta: „Shakespeare év Opheliája.” Abból a célból, hogy a fénykép modern eszközzel megörökítse a futó pillanatban adódó szép akt pózolást, Máté Olga fotóművésztől kért segítséget. A Kelenhegyi úti mütermébe hívta el aktfotó készítésére. Fenella táncra emelt könyöke erősen rövidülő és kissé mesterkélt lett, de Rippl-Rónainak tetszett és több festményébe komponálta. A Róma-villa kiállításának egyik fő műve, a „Modelljeim kaposvári kertemben” címü kép szabadtéri aktjainak sorában a föhelyen áll Fenella, mellette a 12 éves Anella. A rajzalbum „Három akt” című lapján kétszer szerepel Anella, s közte áll Fenella fényképről vett beállítása. Ez a három aktos rajz szolgált az említett, Róma-villában kiállított híres festmény kompozíciójához (9-10. ábra).

Visszatérve a rajzsorozathoz, szólnunk kell azok technikájáról is. Amíg a tanulmányrajznál általában használt hegyes rajztoll állandóan a részletek után szaladt, azt Rippl-Rónai határozottan el akarta kerülni. Játékosan oldott meg egy rajztechnikai problémát. RipplRónai sokak megrökönyödésére az acéltollat kicserélte a durva vastagságú, de jól kihegyezett lúdtollra, máskor meg fapálcikára. A gyártott eszköz széles vonala nem tévedt formai részletekbe, hanem sommázta a legjellemzőbb formarendet. Érdekes, hogy a technikai eszközök szintjén mozgó kreativitás átsegítette a Mestert a stíluselméleti akadályokon is. Már a párizsi korszakban

30 A magyar aktkiállítás albuma. 1926. Mücsarnok. Budapest „A Művészet” kiadása. Szerkesztette: Lyka Károly, Majovszky Pál és Petrovics Elek 
is bebizonyosodott, hogy a stílusfejlődés teóriáján játékosan felszabadított rajzi technikával kerekedett felül. Rippl-Rónai a „homo ludens”, a felszabadult technikai érzékkel játszó, kísérletező művész. A rajzok jellemző tulajdonsága, hogy a vaskos vonalú akt motívum még akkor is uralja a papírlapot, amikor csak néhány vonalból van kanyarítva. Mégis öntörvényü, dekoratív erejü. A korabeli akt pózok beállítása a francia Julian Akadémia krokizó gyakorlatát, a mozdulatok gyors felvázolását célozta. A krokizás elősegítette a teljes alakra irányuló koncentrációt, s egyfajta összesített érzékenységet fejlesztett ki a művészben. A modell könnyed, spontán vonalú körülírása az évszázados francia grafikai ha-

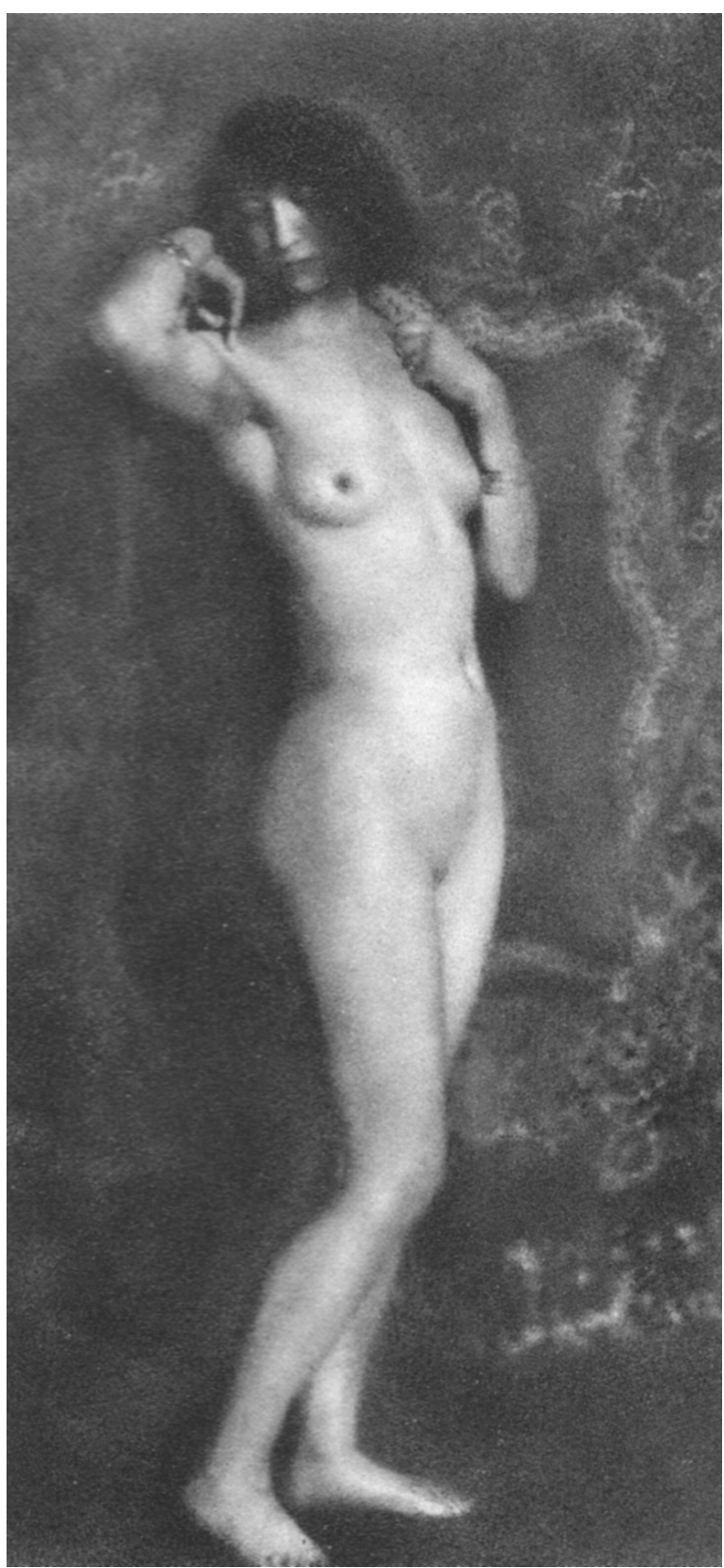

9. ábra. Máté Olga fotója Fenelláról

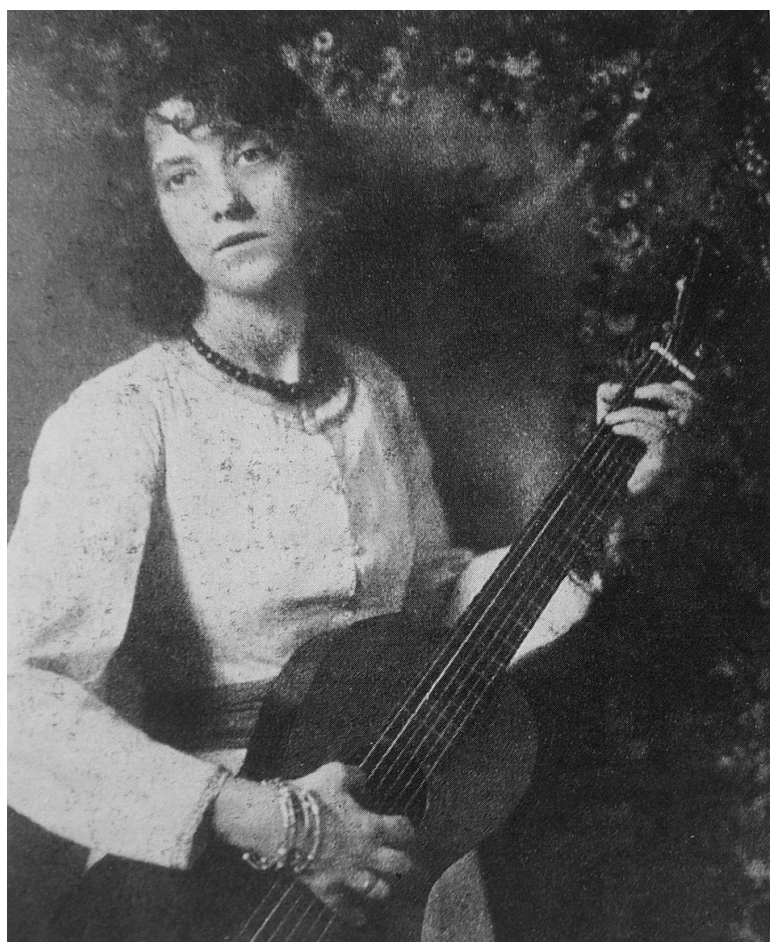

10. ábra. Máté Olga fotója a gitározó Fenelláról

gyományt követte. Abba a rajzkultúrába beletartozik az elrontott, majd kijavított vonal megőrzése. Rippl-Rónai az erőteljes, dinamikus hatás érdekében újította meg a technikát a vastag vonalat húzó lúdtollal. A durva, engedetlen eszköz nem futott akadálytalanul a papíron. A kéz csuklóját ügyesen kellett forgatni a szép ívü szakaszok kanyarításához. Látjuk, amint néha elakad, kifogy a tinta, s a múvész újra húzza még vastagabban, dinamikusabban, mint előtte. A papírfelületet kitöltő vaskos vonalú rendszer az akt motívum öntörvényü életszerűségét, dekoratív szerepét juttatja kifejezésre. Az akt téma elterjedése az 1900-as évek elején sokat lendített előre az európai fauvista festészet kialakulásában (11-13. ábra). Fenella beállásai nem sematikusak, hanem életszerűek, professzionális érzéke segítette a művészt, s bemutatta a nőiesség minden megnyilvánulását. Ruhában vagy aktban pózolt, s közben énekelt. Az akt és drapéria tárgyában intim, erotikusan vetkőző pózokat produkált. Az akt és hangszer ugyancsak klaszszikus párosításaként karcsú alakjához illő gitárral játszott. Az egyik aktos beállításon Fenella zongoraszéken ül és gitárt támaszt magához, a másikon háttal fordulva, korsóval lépked. Amint az aktképekre általában jellemző, a modell arca elnagyolt és személytelen marad. Ez történt Fenellával is. Arckép nem született róla.

A „kukoricás” aktfestmények javarésze elveszett, vagy lappang. Van egy dokumentum, amely alapján tudjuk, hogy mit kell keresnünk. 1911-ben volt „Rippl-Rónai József retrospektiv kiálítása 1888-1911 a Művészházban.” A megnyitón Fenella énekelt. A kiállítás katalógusában szerepel $5 \mathrm{db}$ aktos kép reprodukciója cím és megnevezés nélkül. A katalógussal egy időben készült talán a müvésznek ajándékba, a klisék felhasználásával, 


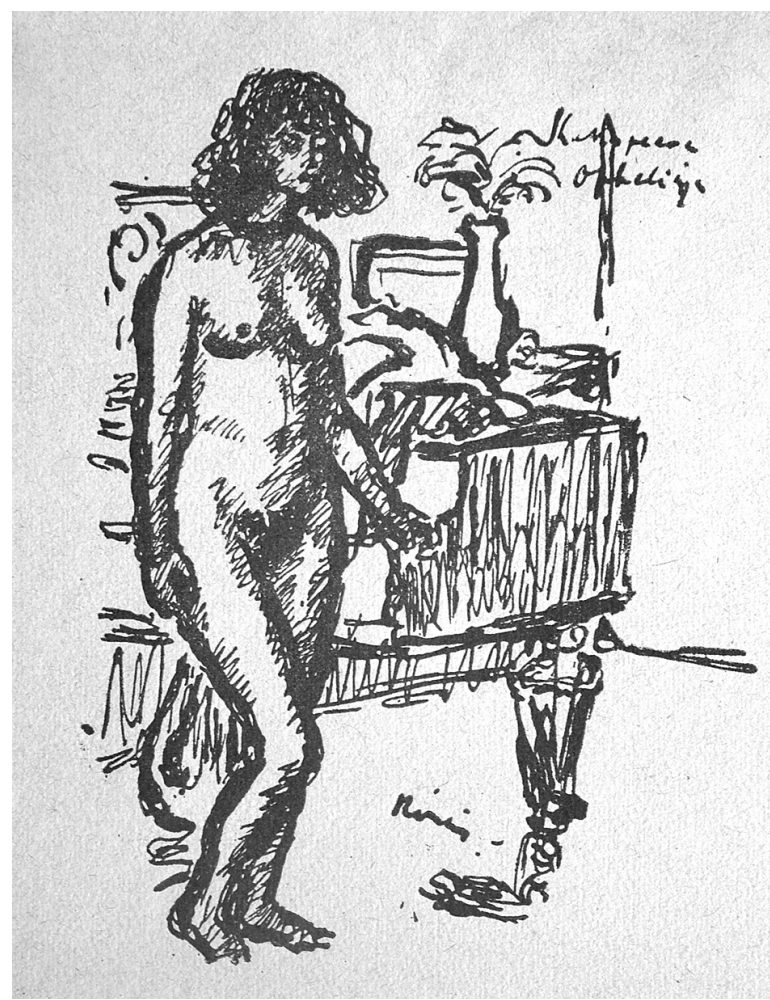

11. ábra. Rippl-Rónai József: Fenella a zongoránál, 1911.

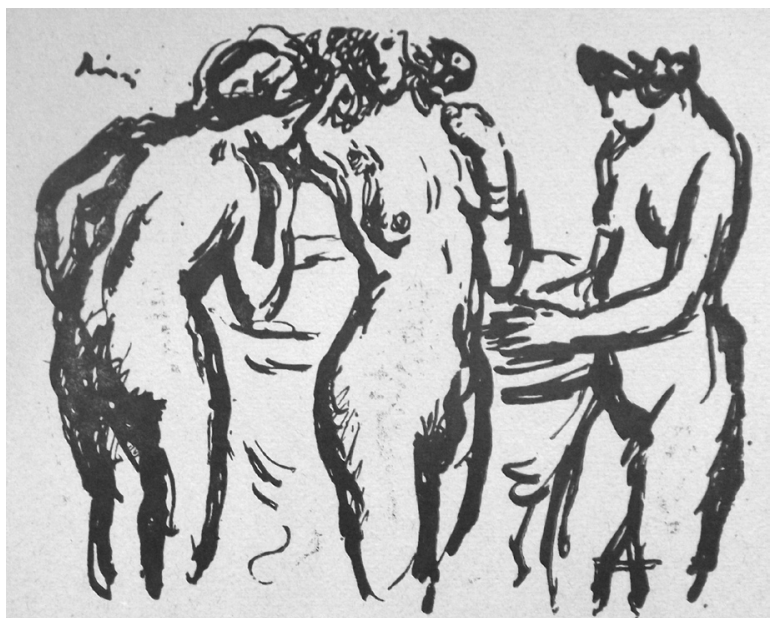

12. ábra. Rippl-Rónai József: Három akt, 1911.

Rippl-Rónai 17 db képéröl fekete-fehér reprodukciókból álló könyvecske, vagy füzet - szöveges rész és képcím aláirás nélkül. ${ }^{31} \mathrm{~A}$ bordó színű kemény borítón nyomtatott Rónai név áll. A Rippl-Rónai Múzeum példányának érdekessége, hogy abba a müvész kézzel írt bejegyzéseket. A katalógus és a bordó könyvecske nyitó képe egy szénnel rajzolt önarckép. Szerepel két korábbi festmény reprodukciója is, az „Ágyban fekvő nő” és az „Apám és Piacsek bácsi vörösbor mellett” című képről, továbbá egy 1910 körüli festmény, melyen Piacsek bácsi az ivánfai szőlő-

31 Rippl-Rónai Múzeum adattára. 1711.

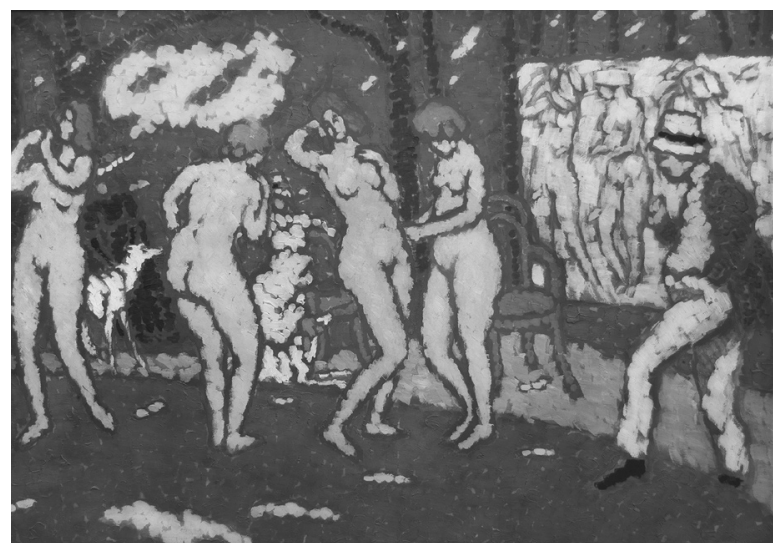

13. ábra. Rippl-Rónai József: Modelljeim kaposvári kertemben, 1911. RRM. tul.

ben terítős asztalnál újságot olvas. A füzetben található $6 \mathrm{db}$ az 50 rajzos album tusrajzaiból és $5 \mathrm{db}$ az eltünt és nagyon jelentős aktos témájú olajképekből. A számunkra érdekes festmények a következők (8., 14-17. ábra).

14. ábra. „Fürdés után” címmel jelölte meg a művész a pesti modelleket ábrázoló képet. $\mathrm{A}$ három akt drapériával kibélelve, nagyon érdekes, gúla-kompozícióba van elhelyezve. Ez megfelel a katalógus VI. teremben jegyzett 25. tételével: „Fürdés után három meztelen lány, olajf. 4000 korona"

8. ábra. Cím nélküli az a két aktos kép, melyen Fenella ül, Anella párnán fekszik a Róma-villához tartozó müterem rikító színű kasmír kendővel leborított kanapéján. Biztos, hogy ez a „Két meztelen leány vörös díványon, olajf. 5000 korona” című kép, mert Rippl-Rónai aláírta, hogy „VI.T. 30 ik” - tehát a VI. terem 30-ik katalógusi tétele.

15. ábra. A következő képen szintén az előbbi két lány szerepel. A kanapén kuporgó Anella a fekvő Fenellára helyezett könyvecskét olvas. A katalógusban ráillik a VI. terem 16. tétele: „Két kis meztelen leány olvas, olajf. 2500 korona"

16. ábra. Cigánykendős kanapén fekvő akt azonos a katalógus VI. terem 13. képével: „Meztelen cigányleány, olajf. 1500 korona" olyan jellegü, mint egy ismert fürdőkádban fekvő női akt Bonnard-tól.

17. ábra. Nagyon szép kompozíciója van annak a képnek, melyiken Anella a fehér lepellel leterített kanapén fekve hallgatja a földön ülö, fehér ruhában gitározó Fenella játékát. A kép azonos a „Gitározó nő és meztelen leány, olajf. 3000 korona” címú katalógusbeli képpel. ${ }^{32} \mathrm{Ez}$ a kép és hat Fenellás tusrajz szerepel a „Rippl-Rónai emlékezései” könyvben is. ${ }^{33}$ Pótolhatatlan hiányt jelent, s a reprodukció alapján is látszik, hogy a főművek közt lenne a helye.

Témakörünk képei biztosan szerepeltek további korabeli kiállításokon, de a katalógusok megjelölései oly pontatlanok, hogy a beazonosítás lehetetlen. Pél-

32 „Rippl-Rónai József újabb rajzai és festményei” című kiállítás katalógusa: VI.terem 20. tétele

33 Rippl-Rónai Emlékezései. 1911. Nyugat kiadása, 146-147. o. között. 


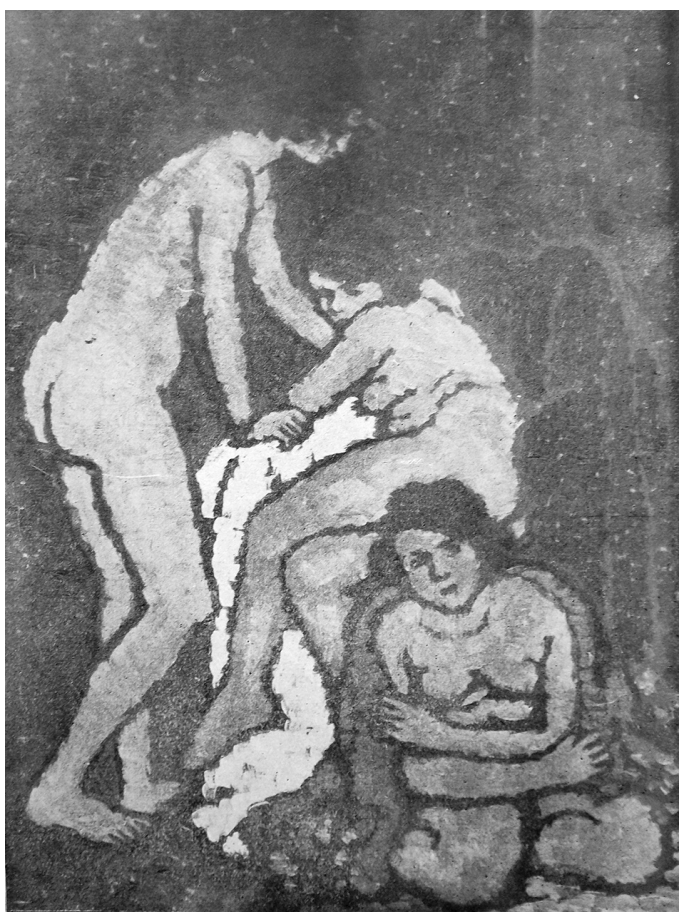

14. ábra. Rippl-Rónai József: Fürdés után három meztelen lány

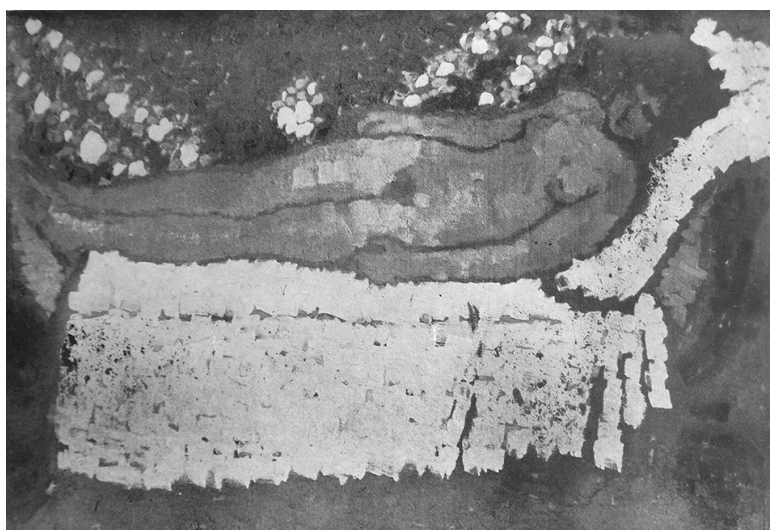

16. ábra. Rippl-Rónai József: Meztelen cigányleány

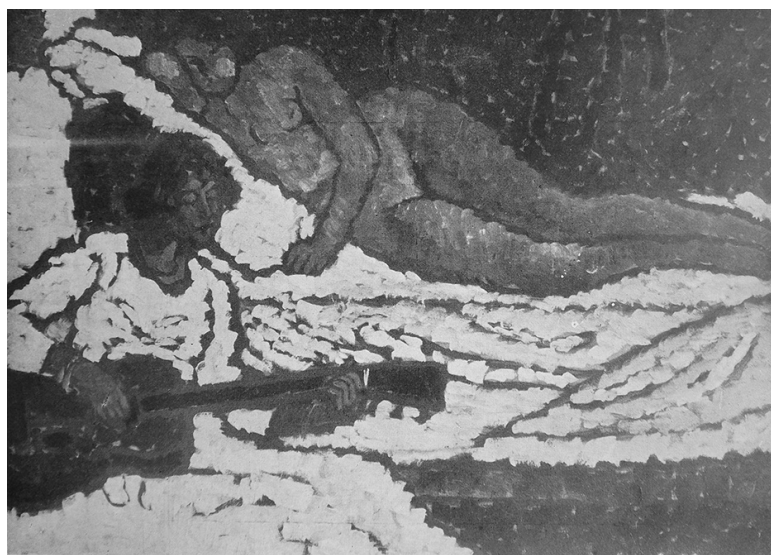

17. ábra. Rippl-Rónai József: Gitározó nő és meztelen leány

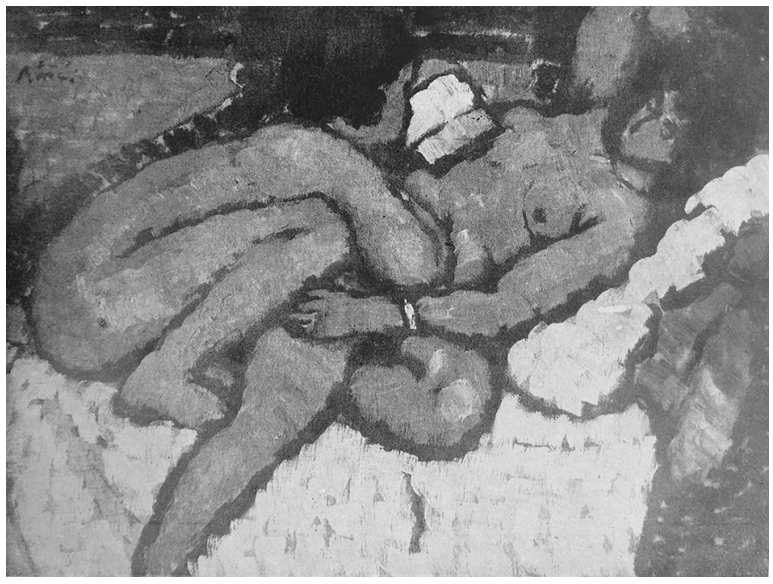

15. ábra. Rippl-Rónai József: Két kis meztelen leány olvas

dául az Ernst Múzeumban 1917-ben rendezett „Ripp/Rónai József újabb rajzai és festményei” című kiállítás negyedik termében 115. tétel szerinti „Modellek” címü képe bármelyik lehet a soroltak közül. Az Ernst Múzeum rendezte 1928-ban „Rippl-Rónai József emlékkiállítása” katalógusában találunk 188. szám alatt „Fenella a díványon. 1911. Magántulajdon” tételt. A Fenellaciklus olajképei Rippl-Rónai művészetének ismeretlen csúcspontját sejtetik. Bízunk az előkerülésükben.

Visszatérve ahhoz a megállapításhoz, hogy itt az 1910-es évtized legmodernebb Rippl-Rónai-rajzaival állunk szemben, arra gondolunk, hogy az új rajztechnika nem csak kontúrozza, hanem behatol a formákba. Mintha a figura sziluettjének sziluettszerű elfedésére törekednék. A rajz ettől nagyobb nyomatékú, festői motívummá alakul át. A női alakok hatékonyabbak lettek, mint akár a kroki, a vázlat, vagy a tanulmány. Valójában új képi motívumokat kísérletezett ki a múvész, amely beillik a fauvista festészet irányzatába.

Fenella bekerült Kaposvár zenei kultúrájába is. Fellépett a kaposvári filharmonikusok 1910. szeptember 26-i estélyén. „A zenekedvelők hangversenyén Rippl-Rónai felfedezettje, Lowell Fenella párizsi cigánylány is szerepelni fog. "'34 Elképzelhető, hogy Fenella olyan előadóművész volt, mint a huszadik század folk-song előadói. A kaposváriak akkor nevezték el Fenellát „Fenelánynak”. Rippl-Rónai Budapesten két alkalommal nagy sikerrel szerepeltette Fenellát. Előadására felfigyelt Bartók Béla is, s RipplRónai budapesti mütermében többször felkereste és énekeltette a lányt.

Fenella oly természetesen beilleszkedett RipplRónaiék családjába, hogy a végén túlzásba vitte. - „Eddigi nyugodt, egybehangolt életünket feldúlta durcáskodásaival és elégedetlenségeivel. Egyszer azután Lazarine néni elvesztette türelmét és kikérte magának ezt a magatartást. Fenella sirás-rívás közepette kijelentette, hogy visszamegy Párizsba. Így is történt a kilenc hónapi tartózkodás után. Ekkor már egészen

34 Somogyi Napló. 1. 1910.66.3.p. továbbá: Somogyvármegye 6. 1910. 3.3-4.p. .Modern estély Kaposváron. 
jól bírta a magyar nyelvet is. Harag nélkül váltunk el tőle és a későbbi évek folyamán is élénk levelezésben voltunk vele" - olvashatjuk a már idézett Anellától. ${ }^{35}$ Fenella Rippl-Rónaiékhoz írt leveleiben derüsen hangoztatta, hogy szívesen vállalta a Magyarországon kapott cigány énekesi titulust. A Magyar Nemzeti Galéria adattárában olvasható levelében megírta, hogy Párizsban franciára fordította és megzenésítette Ady Endre „A halál rokona” című versét.

\section{Levél Rippl-Rónai József leányától, Amélie Feigltől}

Rippl-Rónai Józsefnek nemcsak fogadott, hanem édes gyermeke is volt. A titokról két forrás alapján szereztünk tudomást. Az első dokumentum a mủvész fogadott leányától, Paris Anellától származik. ${ }^{36}$ Rippl-Rónai maga beszélt róla fogadott lányának, Anellának.

„Külföldön leánya csak egy volt - aki müncheni tartózkodása utáni időben született. Erről az egy leányáról is az 1910-es müncheni átutazásunk alkalmával szerzett tudomást, Wellisch Andor révén, akit az ügy felkutatásával megbízott. Így tudta meg, hogy leánya, Amália, Udinében egy olasz grófnőnél társalkodónő lett. Józsi bácsi ekkor elmondta nekem, hogy nemcsak én vagyok a kisleánya, de van neki egy felnőtt leánya is, akivel ettöl kezdve hosszabb levelezést folytatott.

Ebből az időből őrzök egy levelet, amelyben Amália férjhezmenetele alkalmával kapott ajándékot francia nyelven megköszöni. A levél Lazarine nénihez van címezve. Ezúttal egy fényképet is küldött, amelyröl felismerhető volt, hogy ő a Józsi bácsi leánya. A későbbi évek folyamán három szép kisfiának fényképeit is elküldte, akik közül a középsőnek arcvonásai nagyapjának arcvonásaira emlékeztettek."

Rippl-Rónai 1887-ben hagyta el Münchent, tudva azt, hogy egy német lány terhes lett tőle. 23 évig furdalta a lelkiismeret azért, mert nem tudta, fia vagy lánya született-e, s milyen sorsra jutott. 1910-ben szánta rá magát, hogy Wellis Andor, Münchenben dolgozó építész segítségével nyomoztat utána. Anella hagyatékából került a Rippl-Rónai Múzeumba a levél, amelyet elsőként itt publikálunk. Az arisztokrata körök etikettje szerint, Amélie megbántotta volna Rippl-Rónai feleségét, ha közvetlen érintkezésbe lépett volna az apjával. Tehát Rippl-Rónai házának asszonyát, Lazarinet szólította meg. A feladói cím jelzi, hogy Amélie Feigl Udinében egy bizonyos contessa Puppinál, a munkaadójánál lakott. A Puppi név és a levélen szereplő címzés ismeretében lehetséges volna Amélie leszármazottainak felkutatása.

„A. Feigl, Moimacco Udine presso contessa Puppi ${ }^{37}$ 1911. 8.10. este 11 óra

Kedves Asszonyom!

Nem találok szavakat, hogy megköszönjem Önnek ezt a szép ajándékot. Ez egy igazán nagyon kedves

\footnotetext{
35 Horváth János: Rippl-Rónai emlékkönyv. Paris Anella visszaemlékezései Rippl-Rónai Józsefről. Kaposvár, 2008. 35.

36 Horváth János: Rippl-Rónai emlékkönyv. Paris Anella visszaemlékezései Rippl-Rónai Józsefről. Kaposvár, 2008. 35.

37 Franciából fordította: Orbán Szilvia
}

emlék. Látom; amit már remélni sem mertem; hogy tartogat még a világ számomra jószívü embereket. Sírtam az örömtöl, s el sem tudom mondani, mennyire örülnék, ha megölelhetném, s hálámat kifejezhetném.

Úgy tetszik számomra, mintha egy hosszú álomból ébredtem volna, s mintha a szerencse ajtaja nyílott volna ki ebben a percben.

Nem fogja elhinni, de számomra a legnagyobb boldogság tudni azt, hogy vannak akik szeretnek, s akiket őszintén szerethetek. Ez a gondolat önmagában már gazdaggá tesz. Minap válaszoltam az én kedves papámnak; mennyire szép ez a szó! A portréját nézve annyira szeretem, mintha mindig is ismertem volna. Ugye megérti ezt kedves Asszonyom! S a legnagyobb vágyam az lenne, hogy ezt a két jó szívet személyesen is láthassam. Kérem segítsen ennek megvalósításában. Mennyire hálás lennék önnek!

Mégegyszer köszönöm Önnek tiszta szívemböl ezt a szép gyürüt!

Maradok csókolva,

Az ön szerető Amélije.

Kérem Önt, ölelje át helyettem az én kedves papámat, s ne feledjen engem.

Jó éjszakát!

Ugye ír még nekem!"

\section{Egy hamisítási ügy nyomában}

Témánk a legkorábbi Rippl-Rónai-hamisításokat járja körül. Azokat a női pasztellképeket, amelyek még a művész életében készültek jó képességű hamisítók által. Teljesen egyformának látszó, duplumokat soha nem festett Rippl-Rónai, bármennyire jó minőségűnek hat mindkettő. A két összeállított párosítás (18-21. ábra) egyformának tűnő képei közül csak az egyik Rippl-Rónai József eredeti alkotása. Mindkét esetben a jobb oldalon áll az eredeti. A hamisítványok ugyanazon kéztől valók, véleményünk szerint Fried Páltól.

A bal oldali Zorka-kép 2000. márciusban tủnt fel a Müterem Galéria Tavaszi Képaukcióján. Az eredetijével itt szembesítjük. A két kalapos nő összevetése egyszer már megtörtént, de véleményünk szerint téves következtetéssel. ${ }^{38}$ A Zorkáról készült jobb oldali kép 2015 2016-ban Kaposváron a Róma-villában szerepelt letétként. A párba állított ügyes hamisítványok készítőjének módjában állt az eredeti példányokat hosszú időre magához venni, kibontani a rámából és lekopírozni. $A z$ eset egy eredeti képekkel rendelkező képgalériával történő együttműködést feltételez. Az itt tárgyalt eset nyomozásakor valószínūnek vehető feltételezésekbe bocsátkozunk.

Vegyük sorra az eredeti és a hamis képek közötti eltéréseket. Szembetűnik a pasztellkréta eltérő kezelése és az árnyalatok és a sötét tónusok különbsége. A bal oldali „Zorka kékköves gyűrűvel” és „Lazarine elgondolkozik" című képek érdes, differenciálatlan textúrával rendelkeznek. A sötét tónusok uralják a képet. A jobb oldali párjuk finomságra törekvő festői fejlesz-

38 Faragó József.: Melyik igazi, melyik hamis? In.: Népszabadság, 1993. aug. 10. 


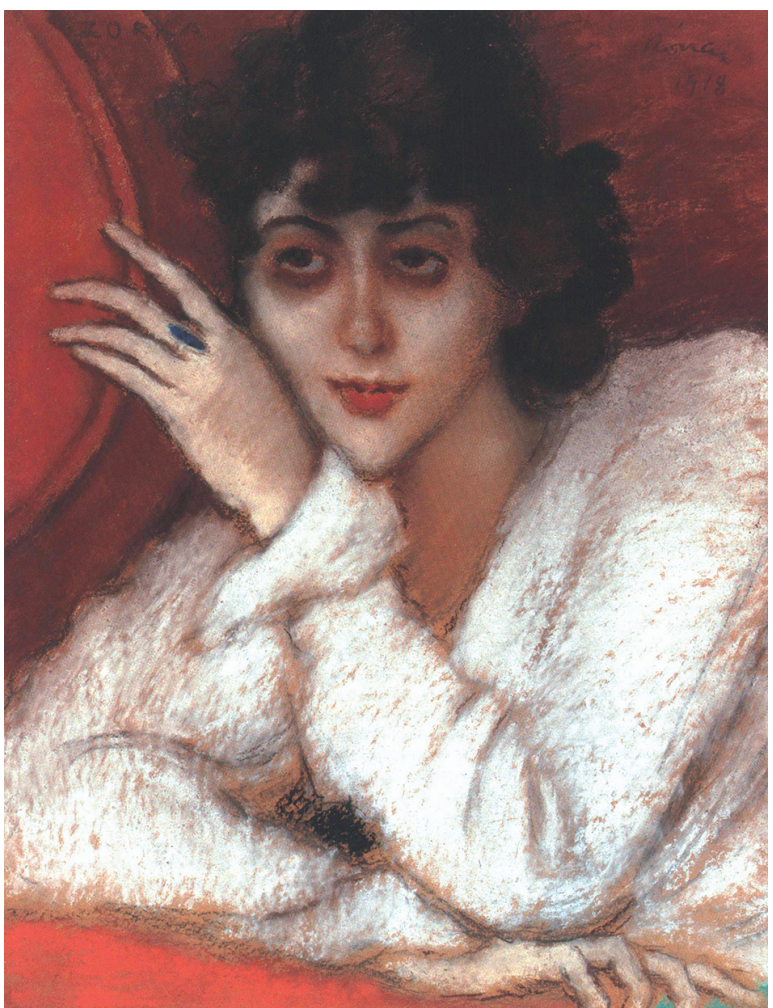

18. ábra. Hamisítvány: Zorka kékköves gyürüvel Mgt. pasztell, papír, 49,5×39,5 cm, jelzés balra fent: ZORKA, jobbra fent: Rónai 1918.

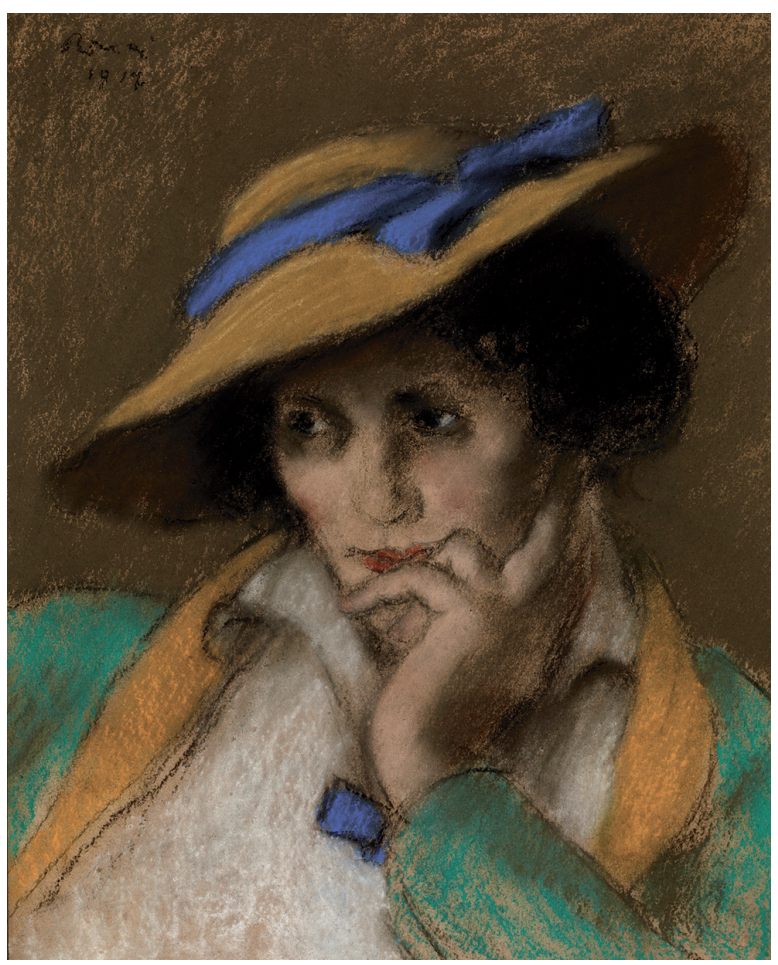

20. ábra. Hamisítvány: Lazarine elgondolkozik. Mgt.

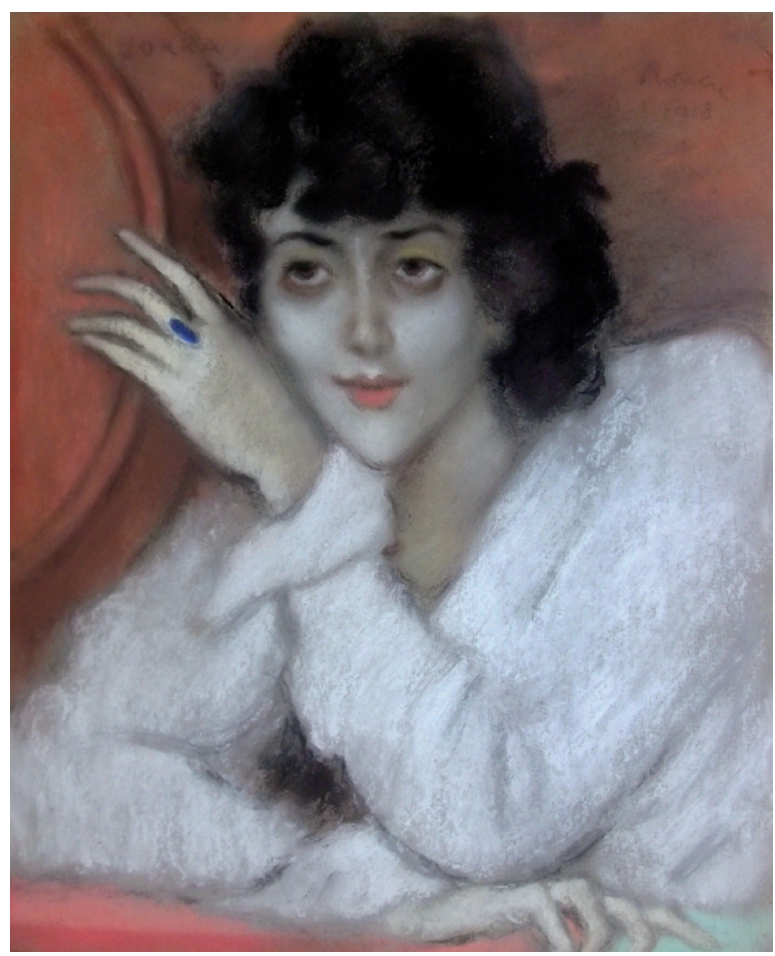

19. ábra. Eredeti: Zorka piros fotelben, 1918. Mgt. pasztell, papír, $52 \times 42 \mathrm{~cm}$, jelzés balra fent: ZORKA, jobbra fent: Rónai 1918.

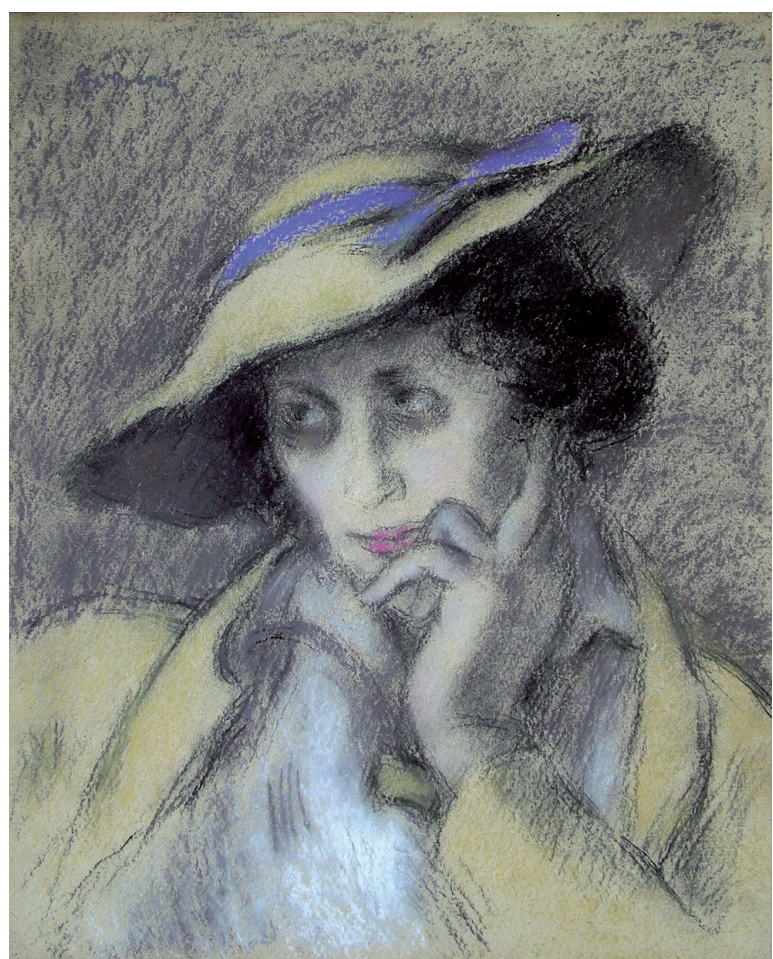

21. ábra. Eredeti: Kalapos nő kék szalaggal. 1917. MNG tul. 
tési fokozattal készült, s jól látszik a részleteket megformáló tiszta, mesteri rajz. Ez kvalitásbéli különbség a jobb szélen lévő képek javára. Az arcok érzelmi kifejeződése tartalmilag módosult a hamisító keze által húzott vastag fekete kréta nyomán. A bal oldali közönséges, züllött jellemmé változott. $A$ jobb oldali hölgyek üdék és hamvasak. A fehér blúzok festésekor mindkét bal oldalin krétázás alla-príma jellegű, ám a várt bravúrt lerontja a durván hagyott faktúra. A jobb oldali képek fehér ruházata festőileg megoldott, s felette áll az elöbbi rögtönzéses állapotúnak. A blúzok felületén játszó érzékeny plasztikai dinamizmust a hamisító nem tudta oly könnyed rutinnal, dekoratív egységben érzékeltetni, mint Rippl-Rónai teszi. A rajzi effektusok, a fekete krétával húzott vastag és vékony vonalak öszszehasonlításakor a rajztudás szintjében mutatkozó lényegi különbségek vannak a hamisítványok rovására. $A z$ eredetin a szemek plasztikus érzékeltetése RipplRónai keze nyomán tisztán értelmezett és határozott. A hamisító mindkét esetben milliméteres különbséggel elvétette a szem tengelyét. A „Lazarine elgondolkozik” kép szeme szétágazik. A hamisítványok legrejtettebb hibája az un. járomcsontok torzulása, az egymáshoz képest történő elcsúszása. A járomcsontdudorok a képzelt középtengelyhez képest aszimmetrikusak. A szemek alatti „karikás” árkok összehasonlításban az eredeti szemek finomabban árnyalt tónusban vannak festve és szervesen illeszkednek a koponyába. A szemek a hamis képek esetében esetleges és bizonytalan helyre kerültek az arcon. Ha a két hamisnak tartott kép kartonlapját és a rajta megkötött pasztellkréta állagát vizsgáljuk, nem lehet kifogásunk. Egykorúnak tűnnek az eredetikkel. A „Rónai” szignók vonalvezetése önállótlannak, másoltnak bizonyul.

A kutatásunk szerint a jelen hamisításokkal összefügg Szíj Béla információja. ${ }^{39}$ A hamisítási ügyekben jártas mủvészettörténész állította, hogy budapesti mügyűjtői körökben ismert tény, hogy a Frankel Szalon Fried Pállal készíttetett hamisítványokat. Így lehetett, hogy az 1928 decemberében az Ernst Múzeum által rendezett 100. kiállítás, Rippl-Rónai József Emlékkiállításának $245 \mathrm{db}$ műve között 5-6 db hamisítvány szerepelt. Az a gyanú, hogy Fränkel adta be őket és kijárta Ernst Lajosnál, hogy a katalógusban a „Lazarine elgondolkozik" címú hamis pasztellreprodukciója szerepeljen. Erről a képről megjelent újságcikkben Csernitzky Mária véleményével szemben mi egy alapos összevetés után, a „Lazarine elgondolkozik” címüről állítjuk, hogy hamisítvány. ${ }^{40}$ Továbbá megállapítottuk, hogy a Magyar Nemzeti Galéria tulajdonában lévő „Kalapos nő kék szalaggal” címü kép eredeti. Az 1932-ben a Fränkel Szalon által rendezett Rippl-Rónai emlékkiállításon már ötnél több hamisítvány szerepelt. Lehetséges, hogy az itt közölt Zorka-, Lazarineés Anella-hamisítvány is már ott volt. Szíj Béla szerint Genthon István személyesen Fräkeltől szerzett tudo-

39 1979-ben Kaposváron, a Rippl-Rónai Múzeumban tett szakfelügyelet alkalmából.

40 Faragó József.: Melyik igazi, melyik hamis? In.: Népszabadság, 1993. aug. 10 . mást erről, de csak szóban beszélt róla, írásban nem akarta dokumentálni. Genthon publikációt írt a „Művészetben” a Rippl-Rónai-hamisítványokról. ${ }^{41}$ Gyanú alá helyezte Fried Pált és Diener-Dénes Rudolfot, mint az első Rippl-Rónai-hamisítókat.

Rippl-Rónai 1920 utáni képeit, kiváltképp a Zorka témájú pasztelleket a Fränkel Szalon forgalmazta egy szabályos műkereskedelmi szerződés alapján. Páris Anella írja a művészről írt könyvében: „Fränkel képkereskedővel nagyobb pénzösszeget küldetett Zorkának, amely összeget később képekkel egyenlített ki. Ezt az adatot Fränkel Ernő fiától, József barátunktól tudtuk meg, aki az erre vonatkozó levelezést ma is örzi." ${ }^{\prime 42}$ $\mathrm{Az}$ eset 1925-ben történt, $\mathrm{s}$ a jel szerint Fränkel fontosnak tartotta, hogy valamely családtag tudtára adja Rippl-Rónai kirívón könnyelmü és felelötlen ügyét. Fränkel vajon miért szólt Anellának a kényes és intim ügyröl? Lehet, hogy baj volt a törlesztéssel és Lazarine-hoz nem fordulhatott?

Korábban soha nem volt Rippl-Rónainak ilyen kétes természetű üzlete. Otthonában nyilvánosan kezelt jegyzetfüzetet tartott, amelyben pontosan felírta a képeladásait. Például így: „Nemes Marcell kir. tanácsos megvette a „Primavera” képet tízezer koronáért 1916. ápr. 13.” Vagy: „Nemes Marcellnél van 4 db képem. Meztelen asszony, Sárga ebédlő, Parkban nők, Lazarine és Pascin. Nincs még megvéve.” - Példásan körültekintő felelősséggel intézte az anyagi ügyeket. Lehetséges az, hogy a megöregedett múvészt pénzért zsarolta Zorka? 1925-ben történt, hogy ősszel súlyos agyvérzés érte Rippl-Rónait. Betegsége mellett nyomasztó adósság gyötörte. Elgyengült, félig bénult kézzel vesződött a festéssel (22. ábra). Rippl-Rónai nevelt fia, dr. Martyn Róbert számolt be arról, hogy mily hősiesen küzdött a beteg művész az alkotással. Amikor a bénult kezéből kiejtette a pasztellkrétát, vékony gyolcs vászonnal az ujjaihoz köttette. 1927-ben az utolsó önarckép előtt együtt álltak a Róma-hegyi müteremben. „...Ott volt az állványon a piros sapkás és kékberés önarckép. - Tudod, - mondta Józsi bácsi - milyen címet adnék az önarcképemnek?... Halálom elött öt perccel. - Én nem - mondtam, hogy szépítsem a dolgot. Csakugyan elütő volt az eddigi önarcképektöl, öreg, megtört, ősz hajú ember állt elöttünk, aki a nagy messzeségbe néz. Az egyik sárga kartonon vázában csak pár vonással jelzett virágcsokor volt. A vonalak reszketősebbek voltak a megszokottaknál és még csak egy-két sárga szín volt felrakva. Újból odaült eléje, nézte, majd a zöld, meg a sárga pasztellel rajzolt bele, ujjával kissé szétkente. Láttam, nem volt elégedett. Mikor újból a papírhoz ért a kezével, megszólalt: - Tudod, olyan gyönyörü szép pirosat kellene festeni. - De a színek összhangja mégis halvány volt, szinte látszottak az elhaló színek utolsó akkordjai. A nagy csendben egyszerre csak Lazarine jelenik meg. - Mit hozzak magának Munikám? - kérdezte. Egy pohár limonádét! - Nemsokára csakugyan megjelent a harma-

41 Genthon István: Rippl-Rónai és hamisítói. In: Művészet. 2. 1961. 5. 6-8.

42 Horváth János: Rippl-Rónai emlékkönyv. Paris Anella visszaemlékezései Rippl-Rónai Józsefről. Kaposvár, 2008. 104. 


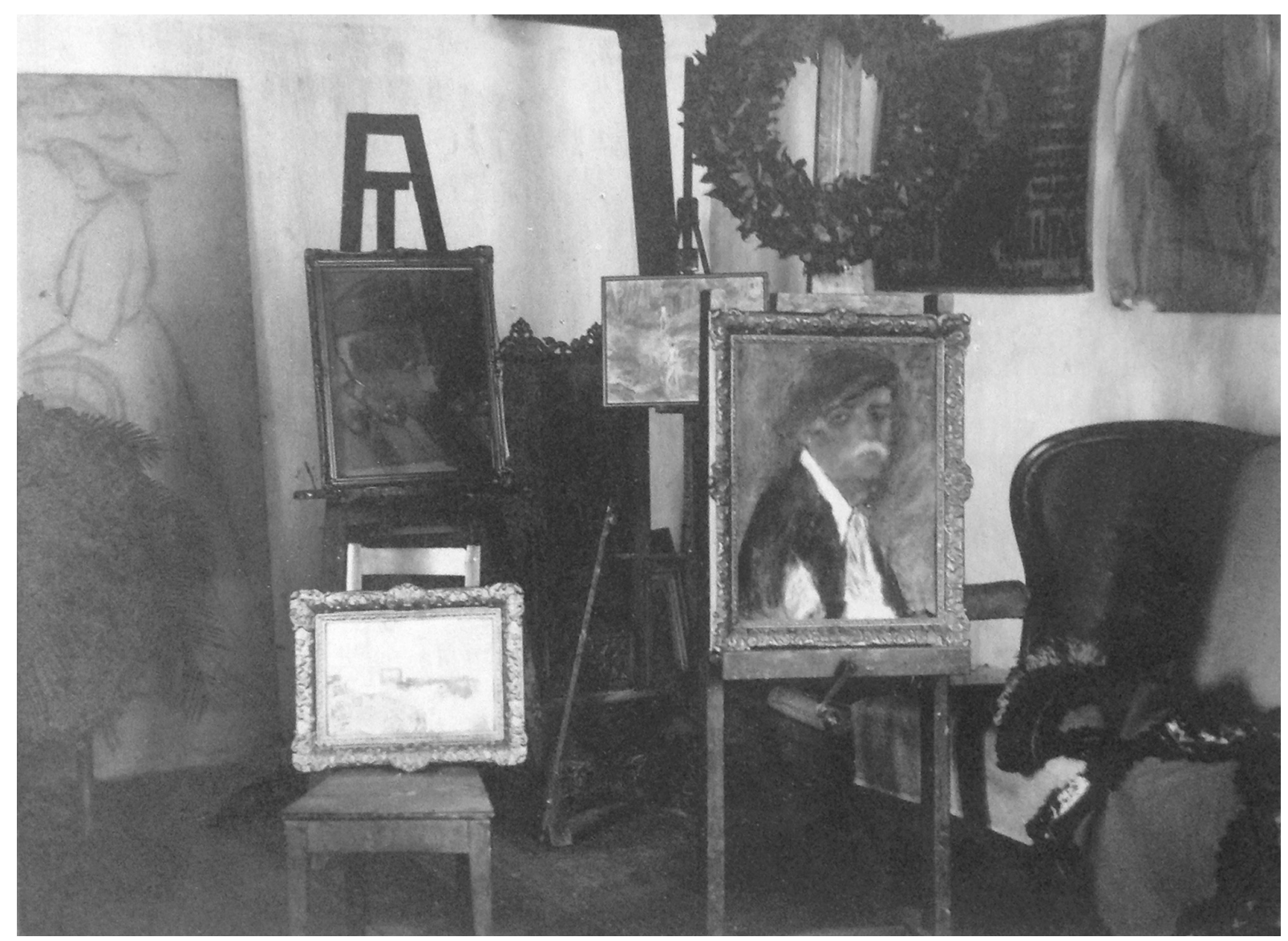

22. ábra. Róma-hegyi müterem a müvész halála után 1930 körül. Festőállványon az Önarckép - „Halálom elött öt perccel.”

tos limonádéval, de mindjárt csitította: - Csak ne sokat. Több mint felét kiitta és nevetett hozzá. Amint igy rakta a virágcsokor színeit, a szokott gyors mozdulatok már hiányoztak. Lassan függőlegesen húzta a vonalakat, aztán megállt. - Megint zsibbad a kezem, szólt hátratekintve. - Hát nem megy, - mondta halkan. - Talán majd máskor. A felrakott virágcsokor mögött a háttér teljesen üres maradt. Pasztelljeit sorbarakta még és becsukta a dobozt. Aztán képére mutatott. - Ezért küzdöttem mondta. - Egész életemben szépet akartam ..." 43

Szemléltetésül közöljük a Lajos öccsét ábrázoló pasztellt (23. ábra). A beteg művész halovány, tétova próbálkozása ez, amely nem tekinthető teljes értékünek. A Fränkel-féle egyezségben ilyen gyenge kép már nem szerepelhetett. A Róma-villa lakói betekintést kaptak a Rippl-Rónait még az élete során sújtó hamisítási ügyekbe. "Hamisitóival szemben is elnéző volt, bár néhányat ismert közülük" - állította Rippl-Rónai Józsefről Anella. ${ }^{44}$ Ezt a kijelentést nem tudjuk mire vélni. Anella nem „csak” a családon belüli konfliktusokra gondolt? Tudtuk, hogy Sándort, az amatőr szinten festő öccsét megrótta, amiért használta a „Rónai” szignót, előre látva a jövőt, hogy azok majd hamisítványokká

43 Martyn Róbert: Egy délután Rippl-Rónaival 1927-ben. In: Visszaemlékezések Rippl-Rónai Józsefre. Somogyi Almanach, 3. 14-15. 44 Uo. 116 válnak. Kis tanítványát, Martyn Ferencet szigorúan leállította az utánzásról. Lazarine nem volt megbocsátó Martyn Ferenccel szemben, özvegysége idején nem fogadta a Róma-villában ${ }^{45}$. A Mester szigorát ismerve nagyon különös Anella közlése. Semmi egyéb jele nincs annak, hogy Rippl-Rónai tudott volna a fenti képeket érintő hamisításról. Még élt, amikor a budapesti mükereskedelem már gyártotta a hamisítványokat. Az első után két újabb agyvérzés érte. Tehetetlenül, drámai helyzetben nézte amint összecsapnak feje felett a mükereskedelem baljós hullámai. Gondolt-e arra, hogy valaha Párizsban Munkácsy Mihály tanítványaként zsírpapírral kopírozta le a kompozíció alakjait, s az általa megfestett másolatot eredetiként szignálta a Mester.

A Zorka-féle viszonyban Rippl-Rónai megalkuvásokba tévedt. Taníttatta, öltöztette, utaztatta, pesti lakást ajándékozott. Úgy tekintett a lányra, mint titkos kertjének virágára. Az életbölcselet magasáról vizsgálta, s türelmesen elviselte szeszélyeit, csakhogy minden nőies titkát festményben rögzíthessen. Eszerint volt szüksége a „nő" közelségére, akkor is, amikor Zorka már mással randevúzott? A Fränkeltől felvett előleg a beígért lakás ára lenne? Lehetséges, hogy a betegen eladósodott müvész egy bonyolult, sötét zsarolási ügy

45 Takáts Gyula naplójegyzete. Somogy 1988. 


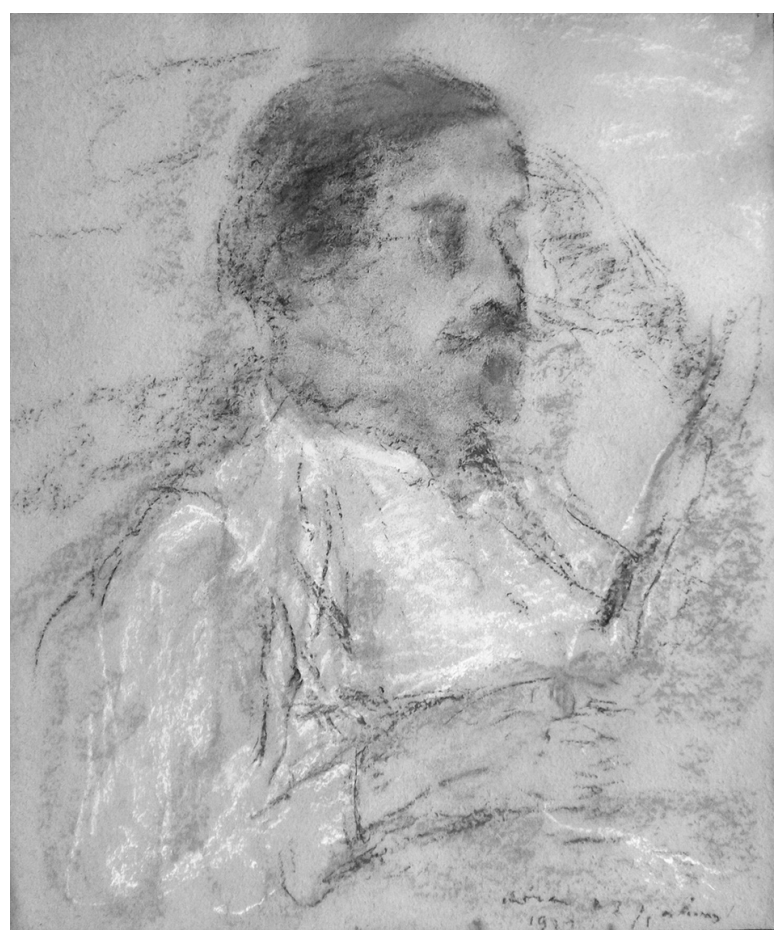

23. ábra. Rippl-Rónai József betegen alkotott képe: Rippl-Rónai Lajos arcképe, 1927. Mgt. Karton, pasztell, $51 \times 41 \mathrm{~cm}$

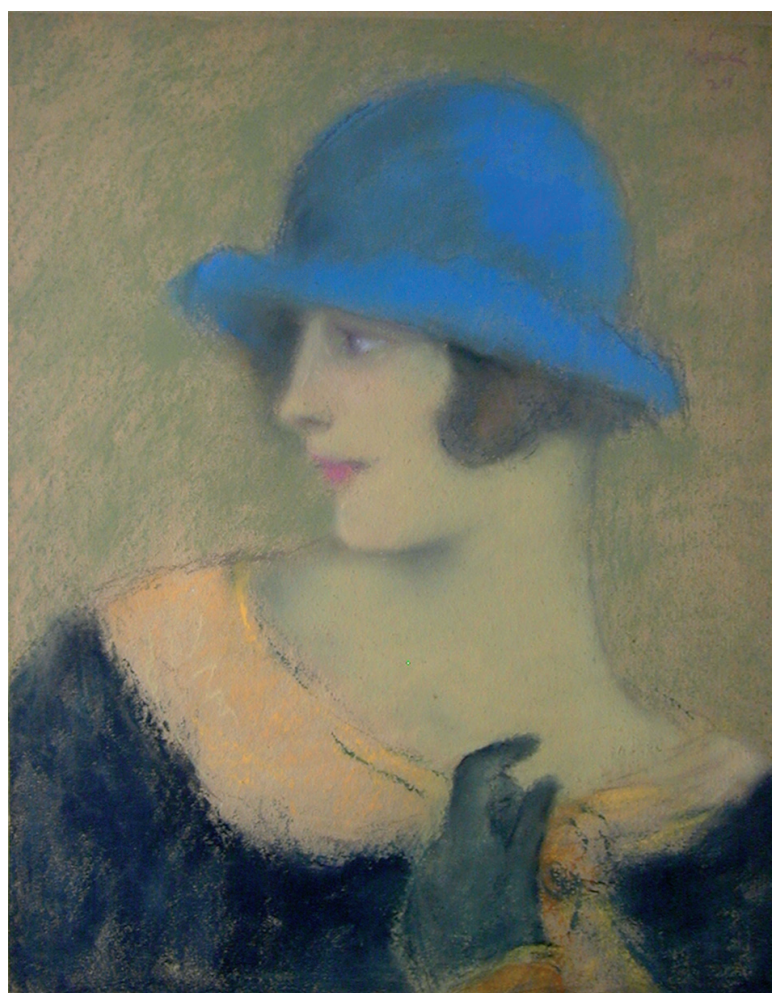

24. ábra. Kék kalapos nő (Anella), Fried Pál Rippl-Rónai-hamisítványa. RRM tul. hálójába került? Vajon Fränkel tudatta-e Rippl-Rónaival, hogy felbérelte Fried Pált, hogy másoljon, amellyel letudja az adósságot? Talán már késő van a válaszhoz. A magunk részéről tapasztaltuk, hogy Fried Pál bizonyult Rippl-Rónai női pasztelljeinek legjobb hamisítójául.

A „Kék kalapos Anella” című kép Fried Pál hamisítványa (24-25. ábra), amelyet a Rippl-Rónai Múzeum az összehasonlító kutatás érdekében vásárolt. Elkészítéséhez nem volt „segítségül” lekopírozható eredeti Rippl-Rónai, talán csak fénykép. Ilyen esetben a hamisító szabadabban „érvényesült” és azzal együtt rosszul utánozta le Rippl-Rónai pasztelles festő technikáját. Elég jól megtalálta az érdes kartonon futó színek, háttéri tónusok faktúrája átvételének módját, a könnyed, energikus futtatást. Ám az ő keze könnyedébb a szükségesnél. A hamis Anella-képen felfedeztünk egy jellemzően Fried Pál-képekről ismert színárnyalatot, egy szürkét, amelyet Rippl-Rónai az arc plasztikai hatásához soha nem használt. Az a szín Fried ezüstös szürkéje, amelyet a hamisításnál alkalmazott. Rippl-Rónai meleg szín-skála rendszerében az a szín giccses. Ez is hozzájárult a hamisító lebuktatásához. Friednek nyilván nem lehetett betekintése Rippl-Rónai krétás dobozába, és nem érzékelte a pasztellképek egyénien kifinomult színharmóniáját. A „Kék kalapos nő - Anella” című kép vezetett nyomra az itt bemutatott hamisítványokhoz. Az együttes vizsgálattal sikerült a „Zorka kékköves gyürüvel” és a „Lazarine elgondolkozik” címü képek hamisított voltának megállapítása.

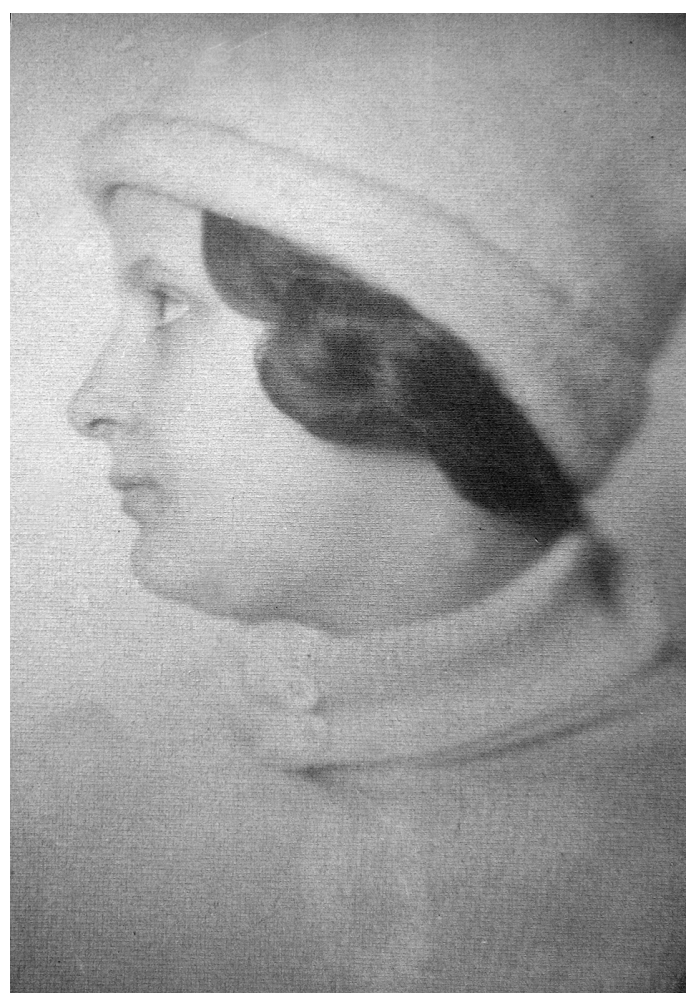

25. ábra. Fénykép Anelláról 
A végére hagytuk a nagyon furcsa 26 . számú képünket (26. ábra), amely cáfolni látszik azt az állításunkat, hogy mesterünk soha nem készített duplumot saját művéről. Itt ugyanis dr. Martyn Róbert hagyatékából rendelkezésünkre áll egy zsírpapírra készült ceruza rajz, melyet saját képére takarva, rászorítva másolta le Rippl. Nyilvánvalóan azzal a szándékkal készítette átlátszó anyagra, hogy megismételje, lekopírozza a női portrét. A könyöklő, telt arcú nő bal válla mögött azok az üvegvázák látszanak, amelyek a párizsi „fekete korszakos” festményeken vannak. A fej fölötti formákból nem egyértelmű, hogy virágos kalapot látunk ott, vagy valami mást. A rajz alatt a következő autográf írás olvasható: „Csanády Ilona WIEN 1892”.

Zárójelbe téve egy további információ is oda van írva: „a festmény nála van mint Reisz Ferencné Párizs”. Ez alapján bizonyos, hogy Rippl-Rónai lemásolta, újra megfestette ezt a képet talán azzal a módszerrel, ahogy a Munkácsy képekről kellett neki másolnia. Azt látjuk, hogy a zsírpapírra került rajz csak a szemeknél, a szájnál, vagyis a karakter vonások érdekében törekedik mereven másolni a kész példányt. $\mathrm{A}$ kompozíciót már lendületes vonal követi, majd a hajat és a ruha fodrát egészen könnyed rajz rögzíti. Megkönnyebbülten nyugtázzuk, hogy ez a másolópapír nem nem segíthet hozzá olyan pontosan körvonalazott duplumhoz, mint a témában szereplő Zorka képeknél. Ott a szignók is fedésben vannak és a két kép között a tiszta rajzolat alapján meg tudjuk különböztetni az első példányt és a durvább, vastagabb vonalú másodikat, a hamisítványt.

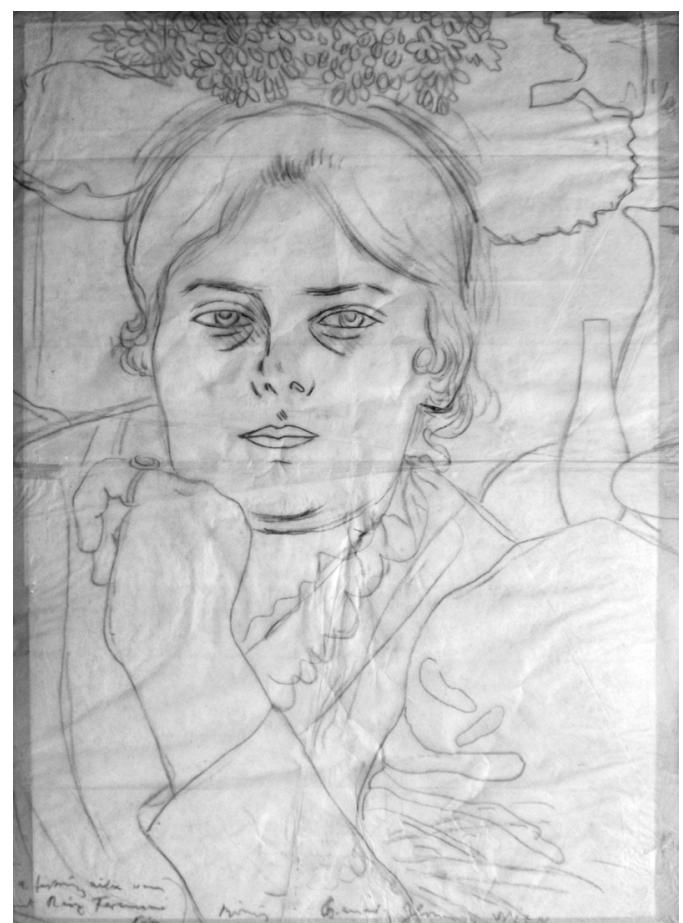

26. ábra. Rippl-Rónai József: Csanády llona arcképe, 1892. Zsírpapír, ceruza, $51 \times 35,5 \mathrm{~cm}$. Rippl-Rónai saját képéről készített másolópapír. Mgt.

\section{Irodalom}

A MAGYAR AKT-KIÁLLíTÁS ALBUMA. 1926: Műcsarnok. Budapest „A Művészet" kiadása. Szerkesztette: Lyka Károly, Majovszky Pál és Petrovics Elek

BÁLINT, A. 1922: Három új Kner kiadvány. Nyugat. 1922. II. 17-18. sz.

CSINSZKA ÖNÉLETRAJZA ÉS LEVELEI. 1937: Sajtó alá rendezte Kárpáti Aurél. Budapest, 1937. Kézirat Petőfi Irodalmi Múzeum, V.4075.4.

GÁSPÁR, F. 2006: Mesterek kiállítása. Nagyvárad, 1916. február. In: Somogy Megyei Múzeumok közleményei. 2006.

Genthon, I. 1958: Rippl-Rónai József. Budapest, 1958. Képzőművészeti Alap Kiadó
GentHON, I. 1961: Rippl-Rónai és hamisítói. In: Művészet. 2. 1961. 5. HoRvÁTH, J. 2008: Rippl-Rónai emlékkönyv. Paris Anella visszaemlékezései Rippl-Rónai Józsefről. Kaposvár, 2008.

LÉVAI, J. GY.: Kaposvári történetek

NATANSON, T. 1949: Fordította és közli: Cs. Szabó László: Rippl-Rónai és Natanson. Magyar Múvészet, 1949. 1. sz.

PEWNY, D. 1940: Rippl-Rónai József (1861-1927), Budapest, 1940.

RIPPL-RÓNAI EMLÉKEZÉSEI. 1911: Nyugat kiadása

RIPPL-RÓNAI JÓZSEF GYÜJTEMÉNYES KIÁLLíTÁSA. 1988: Magyar Nemzeti Galéria 1998. Szerkesztette: Bernáth Mária, Nagy lldikó

VISSZAEMLÉKEZÉSEK RIPPL-RónAI JózSEFRE. Somogyi Almanach, 3. 